\title{
Iron partitioning during LOHAFEX: Copepod grazing as a major driver for iron recycling in the Southern Ocean
}

\author{
Luis M. Laglera ${ }^{\mathrm{a}, *}$, A. Tovar-Sánchez ${ }^{\mathrm{b}, \mathrm{c}}$, M.H. Iversen ${ }^{\mathrm{d}, \mathrm{e}}$, H.E. González ${ }^{\mathrm{f}, \mathrm{k}}, \mathrm{H}$. Naik ${ }^{g}$, G. Mangesh ${ }^{g}$, \\ P. Assmy ${ }^{\mathrm{h}}$, C. Klaas ${ }^{\mathrm{i}}$, M.G. Mazzocchi ${ }^{j}$, M. Montresor ${ }^{\mathrm{j}}$, S.W.A. Naqvi ${ }^{\mathrm{g}}$, V. Smetacek ${ }^{\mathrm{i}}$,
} D.A. Wolf-Gladrow ${ }^{i}$

a FI-TRACE, Departamento de Química, Universidad de las Islas Baleares, Palma, Balearic Islands 07122, Spain

b Department of Ecology and Coastal Management, Andalusian Institute for Marine Science, ICMAN (CSIC), Campus Universitario Río San Pedro, Puerto Real, Cádiz, Spain

c Department of Global Change Research IMEDEA (CSIC-UIB), Instituto Mediterráneo de Estudios Avanzados, Spain

d Helmholtz Young Investigator Group SEAPUMP, Alfred-Wegener-Institut Helmholtz Zentrum für Polar- und Meeresforschung, Am Handelshafen 12, 27570 Bremerhaven,

Germany

e Faculty of Geosciences and MARUM, University of Bremen, Klagenfurter and Leobener Strasse, 28359 Bremen, Germany

${ }^{\mathrm{f}}$ Universidad Austral de Chile, Instituto de Ciencias Marinas y Limnológicas, Valdivia, Chile

${ }^{g}$ National Institute of Oceanography, Dona Paula, Goa, India

h Norwegian Polar Institute, Fram Centre, N-9296 Tromsø, Norway

${ }^{i}$ Alfred-Wegener-Institut Helmholtz Zentrum für Polar- und Meeresforschung, Am Handelshafen 12, 27570 Bremerhaven, Germany

${ }^{j}$ Department of Integrative Marine Ecology, Stazione Zoologica Anton Dohrn, Villa Comunale, 80121 Napoli, Italy

${ }^{\mathrm{k}}$ Centro de Investigaciones de Ecosistemas Marinos de Altas Latitudes (FONDAP-IDEAL), Valdivia, Chile

\section{A R T I C L E I N F O}

\section{Keywords:}

LOHAFEX

Iron cycling

Iron partitioning

Grazing

Southern Ocean

Iron fertilization

Silicate depletion

\begin{abstract}
A B S T R A C T
The LOHAFEX iron fertilization experiment was conducted for 39 days in the closed core of a cyclonic mesoscale eddy located along the Antarctic Polar Front in the Atlantic sector of the Southern Ocean. Mixed layer (ML) waters were characterized by high nitrate $(\sim 20 \mu \mathrm{M})$, low dissolved iron (DFe $\sim 0.2 \mathrm{nM})$ and low silicate concentrations (below $1 \mu \mathrm{M}$ ) restricting diatom growth. Upon initial fertilization, chlorophyll-a doubled during the first two weeks and stabilized thereafter, despite a second fertilization on day 21, due to an increase in grazing pressure. Biomass at the different trophic levels was mostly comprised of small autotrophic flagellates, the large copepod Calanus simillimus and the amphipod Themisto gaudichaudii. The downward flux of particulate material comprised mainly copepod fecal pellets that were remineralized in the upper $150 \mathrm{~m}$ of the water column with no significant deeper export.

DFe concentrations in the upper $200 \mathrm{~m}$ were not significantly affected by the two fertilizations but after day 14 showed a greater variability (ranging from 0.3 to $1.3 \mathrm{nM}$ ) without a clear vertical pattern. Particulate iron concentrations (measured after 2 months at $\mathrm{pH} 1.4$ ) decreased with time and showed a vertical pattern that indicated an important non-biogenic component at the bottom of the mixed layer. In order to assess the contribution of copepod grazing to iron cycling we used two different approaches: first, we measured for the first time in a field experiment copepod fecal pellet concentrations in the water column together with the iron content per pellet, and second, we devised a novel analytical scheme based on a two-step leaching protocol to estimate the contribution of copepod fecal pellets to particulate iron in the water column. Analysis of the iron content of isolated fecal pellets from $C$. simillimus showed that after the second fertilization, the iron content per fecal pellet was $\sim 5$ fold higher if the copepod had been captured in fertilized waters. We defined a new fraction termed leachable iron ( $\mathrm{pH} 2.0$ ) in $48 \mathrm{~h}\left(\mathrm{LFe}^{48 \mathrm{~h}}\right)$ that, for the conditions during LOHAFEX, was shown to be an excellent proxy for the concentration of iron contained in copepod fecal pellets. We observed that, as a result of the second fertilization, iron accumulated in copepod fecal pellets and remained high at one third of the total iron stock in the upper $80 \mathrm{~m}$.

We hypothesize that our observations are due to a combination of two biological processes. First, phagotrophy of iron colloids freshly formed after the second fertilization by the predominant flagellate community resulted in higher Fe:C ratios per cell that, via grazing, lead to iron enrichment in copepod fecal pellets in fertilized waters. Second, copepod coprophagy could explain the rapid recycling of particulate iron in the upper
\end{abstract}

\footnotetext{
* Corresponding author.

E-mail address: luis.laglera@uib.es (L.M. Laglera).
} 
100-150 $\mathrm{m}$, the accumulation of $\mathrm{LFe}^{48 \mathrm{~h}}$ in the upper $80 \mathrm{~m}$ after the second fertilization and provided the iron required for the maintenance of the LOHAFEX bloom for many weeks. Our results provide the first quantitative evidence of the major ecological relevance of copepods and their fecal products in the cycling of iron in silicate depleted areas of the Southern Ocean.

\section{Index terms}

4807 Chemical speciation and complexation

0414 Biogeochemical cycles, processes, and modeling

0461 Metals

0489 Trace element cycling

\section{Introduction}

Thirteen ocean iron fertilization experiments (OIF) (including the current study) have all demonstrated that iron is a limiting nutrient for primary production in all high nutrient, low chlorophyll (HNLC) areas, corroborating the first tenet of the iron hypothesis (Martin et al., 1990). OIF experiments have increased our understanding of the role of iron in biogeochemical processes in HNLC areas and have also shed new light on the importance of other factors such as temperature, local physical dynamics, co-limitation by silicic acid, depth of the mixed layer, ligand concentration, the response of grazers and the influence of dominant diatom species as modulators of carbon and silicon cycles (Assmy et al., 2013; Boyd et al., 2007; Boye et al., 2005; de Baar et al., 2005; Smetacek et al., 2012; Smetacek and Naqvi, 2008; Tsuda et al., 2007).

Previous OIF experiments showed that, immediately following fertilization, dissolved iron ( $\mathrm{DFe}$ ) concentrations increased within the mixed layer (ML) at concentrations below those calculated from a homogeneous distribution of the added iron throughout the ML (Bowie et al., 2001; Croot et al., 2001; Gordon et al., 1998; Kinugasa et al., 2005; Nishioka et al., 2009; Wells, 2003). DFe concentrations in excess of its solubility (Liu and Millero, 2002) are liable to be removed from the ML by precipitation in a time frame of a few hours to a few days (Bowie et al., 2001; Croot et al., 2001; Gordon et al., 1998; Harvey et al., 2011; Nishioka et al., 2005, 2009; Rue and Bruland, 1997). Only in those cases where the experiment was continued for several weeks and several fertilizations were applied, did DFe concentrations in the ML remain high for many days (Bowie et al., 2001; Croot et al., 2001). Furthermore, vertical profiles obtained during previous OIFs have usually shown an exponential decrease of DFe with increasing water depth (Bowie et al., 2001; Nishioka et al., 2005, 2009). Results from these experiments indicate that most of infused DFe is rapidly lost via abiotic processes (Bowie et al., 2001).

Particulate iron has been reported in a wide range of concentrations ranging from 0.2 to $\sim 10 \mathrm{nM}$ (Croot et al., 2004; Chever et al., 2010; Löscher et al., 1997) in the upper water column $(0-200 \mathrm{~m})$ of the Atlantic Sector of the Southern Ocean. Analysis of unfiltered samples during previous OIF experiments showed an immediate increase of particulate iron upon fertilization $(0-6 \mathrm{nM})$ followed by a rapid decrease similar to that measured for DFe (Nishioka et al., 2009). However, during SOIREE, retention of particulate iron in the ML at the end of the experiment for a period of many days was reported (Bowie et al., 2001). Subsequent iron additions during EisenEx also resulted in significant increases in particulate iron in the mixed layer that were removed by storm events (Nishioka et al., 2005). Since colloidal or particulate inorganic iron can be made bioavailable by biological processes such as phagotrophy (the engulfing of particulate/colloidal food inside cells, often involving particles significantly larger than the feeding cell) (Maranger et al., 1998; Nodwell and Price, 2001) or after extraction from mineral phases by dissolved organic ligands naturally present in seawater (Fishwick et al., 2014), understanding of iron cycling requires insight into the amount of iron that is incorporated into the biological community (Bowie et al., 2001).
Here we present data on the concentration and partitioning of iron in the upper $200 \mathrm{~m}$ of the water column measured during the LOHAFEX experiment. The role of grazing on controlling phytoplankton biomass during natural blooms and OIF experiments is well documented (Landry et al., 2000; Saito et al., 2006; Smetacek et al., 2004). Although the role of grazing on promoting iron recycling has been invoked (Bowie et al., 2001) and studied in incubations (Nuester et al., 2014; Sarthou et al., 2008; Sato et al., 2007), at this stage it is still poorly defined for natural conditions.

Particulate iron is often determined after prolonged and strong acidification making it impossible to characterize the contribution of different types of biological and mineral particles (Chever et al., 2010; Löscher et al., 1997). Since, during LOHAFEX, POC was efficiently recycled in the upper $150 \mathrm{~m}$, we investigated the role played by copepod fecal pellets, the major component of settling particles, on iron cycling (Martin et al., 2013). First, we developed for the first time a trace clean protocol to collect and analyze fecal pellets freshly released by large copepods and combined this measurement with microscopic counts of copepod fecal pellets in the water column. Second, we also devised and implemented a novel fractionation scheme not based on the traditional use of filters of different pore size but based on the different leaching kinetics for iron in particles of different nature and at different $\mathrm{pH}$ values. Onboard experiments with cultured phytoplankton cells and suspensions of copepod fecal pellets showed that for our experimental conditions, room temperature acidification at $\mathrm{pH} 2.0$ for $48 \mathrm{~h}$ was an excellent proxy for the iron contained in copepod fecal pellets. The combination of both analytical approaches allowed us to assess for the first time the storage of easily leachable iron in copepod fecal pellets (about one third of the iron stock during the second half of the experiment). Grazing by copepods during LOHAFEX not only kept the build-up of plankton biomass in check but the fast recycling of its fecal products regenerated the iron necessary for supporting primary production and maintaining higher biomass for many weeks.

\subsection{LOHAFEX}

The Indo-German OIF experiment LOHAFEX was conducted to investigate the effects of iron fertilization on the plankton community of the southwestern Atlantic Sector of the Southern Ocean (on board the R/V Polarstern, cruise code ANT-XXV/3) (Smetacek and Naqvi, 2010). In order to contain and limit patch dilution LOHAFEX was carried out in the closed core of a cyclonic mesoscale eddy found north of the Antarctic Polar Front $\left(48^{\circ} \mathrm{S}, 15^{\circ} \mathrm{W}\right)$ selected based on altimetry analysis (Fig. 1A). This sector of the Southern Ocean receives more natural iron than other parts of the Antarctic Circumpolar Current (ACC) and Chl-a

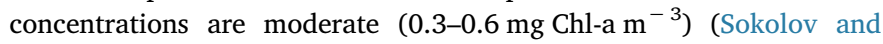
Rintoul, 2007). Recent studies have reported that higher iron levels in this region are mainly sustained by the ACC, which receives and transports high DFe concentrations eastwards (De Jong et al., 2012), and from upwelling of fertilized waters due to mesoscale frontal dynamics (Meskhidze et al., 2007).

LOHAFEX started on 27 January 2009 when a quantity of 10 tons of iron sulfate heptahydrate corresponding to 2 tons of $\mathrm{Fe}(\mathrm{II})$, previously dissolved in acidified seawater $(\mathrm{HCl}, \mathrm{pH}=2)$ and labeled with $\mathrm{SF}_{6}$, was released in a spiral pattern in the center of the selected eddy covering a surface area of $\sim 300 \mathrm{~km}^{2}$ that was sampled over 39 days (Fig. 1A). As the mixed layer depth was $\sim 50 \mathrm{~m}$ at the time of fertilization (Martin et al., 2013), instant mixing would have resulted in an initial DFe concentration of $\sim 2.4 \mathrm{nM}$ throughout the patch (an increase of the DFe standing stock of $\sim 120 \mu \mathrm{mol} \mathrm{Fe} \mathrm{m}^{-2}$ ). 


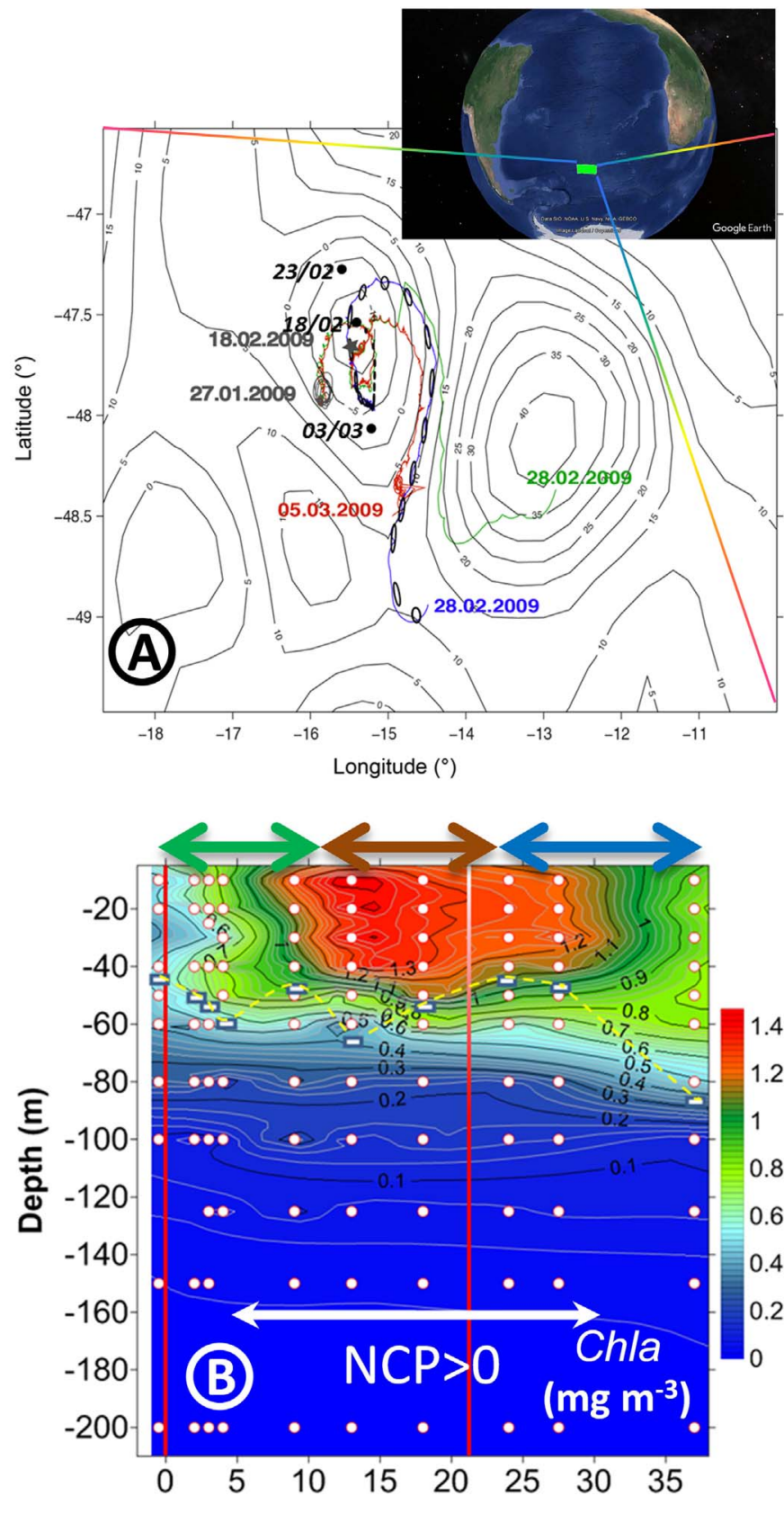

\section{Time since first fertilization (days)}

Fig. 1. A: Globe map (Google Earth) showing the location of the LOHAFEX experiment with satellite altimetry of the eddy at the time of the first fertilization (27 January 2009). The gray line shows the fertilization spiral. Colored lines show the trajectories of the buoys deployed to track the fertilized patch with dates in color corresponding to the buoy positions at the end of their trajectories. Black ellipses show the modeled position of the center of the patch (see Martin et al., 2013 for details). Black dots show the position of the OUT stations. The gray star marks the location of the patch at the time of the second fertilization (18 February 2009). B: Temporal evolution of Chl-a concentrations (in

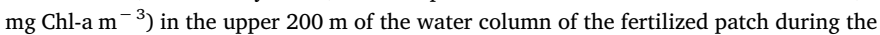
LOHAFEX experiment. The white double arrows mark the period characterized by positive net community production (Martin et al., 2013). The MLD is indicated by white rectangle symbols connected by the yellow dashed line. The different stages of the experiment are indicated by the double arrows on the top of the panel (green: growth-stage, brown: grazing-stage and blue: dilution-stage). The altimeter products were produced by Ssalto/Duacs and distributed by Aviso, with support from Cnes (http://www.aviso. altimetry.fr/duacs/). (For interpretation of the references to color in this figure legend, the reader is referred to the web version of this article.)
On day 21 of the experiment, after an observed decrease of the surface Chl-a concentration, another 10 tons of ferrous sulfate were released along longitudinal transects across the patch while the circulation moved the patch within the eddy. LOHAFEX is the largest and longest OIF experiment conducted to date.

\subsection{Overall LOHAFEX features}

A detailed account of the sampling methodology of ancillary parameters, preliminary data obtained onboard, and an overview of the physical evolution of the fertilized patch, can be found elsewhere (Martin et al., 2013; Smetacek and Naqvi, 2010).

Prior to the first iron fertilization, the vertical distribution of Chl-a to a depth of $60 \mathrm{~m}$ was nearly homogeneous at a concentration of 0.4-0.5 mg Chl-a m ${ }^{-3}$; below $60 \mathrm{~m}$ the concentration diminished rapidly and was below detection limits at $100 \mathrm{~m}$ (Fig. S1). The concentrations of nutrients in the ML were $\sim 20 \mu \mathrm{M}$ for $\mathrm{NO}_{3}{ }^{-}, \sim 1.2 \mu \mathrm{M}$ for $\mathrm{PO}_{4}{ }^{3-}$, and $<1 \mu \mathrm{M}$ for silicate (Smetacek and Naqvi, 2010). Low silicate concentrations led to an ecological community different from what was anticipated, thus making it necessary to redefine priorities and analytical procedures as the experiment progressed.

The effect of the iron fertilization was manifested by: i) a doubling

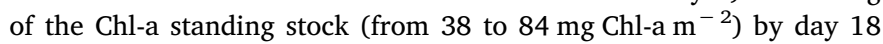
(Figs. 1B and S2); ii) an increase of the photosynthetic quantum efficiency $(F v / F m)$ ratio from an initial $\sim 0.33$ to $0.4-0.5$ for the rest of the experiment, indicative of relief from iron limitation (Martin et al., 2013).

Despite dilution and patch fragmentation during the last week, the Chl-a stock decreased only moderately to $64 \mathrm{mg} \mathrm{m}^{-2}$ by the end of the experiment. Chl-a stocks varied also at the OUT stations (Fig. S2), and

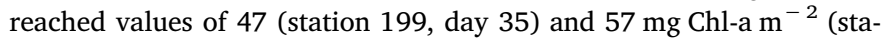
tion 160, day 23). A general minor accumulation of Chl-a south of the Polar Front, including the unfertilized waters of the eddy during LOHAFEX, was apparent from satellite images obtained 18 days into the experiment (Figs. S2 and S3). This natural dynamic was important since many biological and chemical variables, including DFe in surface waters, showed similar values at IN and OUT stations during the five weeks the experiment lasted. For instance, there was a similar increase of the grazing pressure and bacterioplankton numbers, both in fertilized and unfertilized waters (Martin et al., 2013; Thiele et al., 2012). The second fertilization had no significant effect on any of the biological or chemical parameters monitored.

The fertilized patch rotated clockwise inside the eddy core and maintained its coherence until day 32 (Fig. 1A). Thereafter the shear effect of a nearby anticyclone scattered the patch in filaments. Modeling, supported by satellite images and $\mathrm{Fv} / \mathrm{Fm}$ measurements, suggested that the "hot spot" of the patch was diluted by about $50 \%$ after day 20 and by about $80 \%$ by day 39 (Martin et al., 2013).

Three major results from the LOHAFEX experiment, relevant for the interpretation of iron partition data, can be highlighted. First, the plankton composition - prokaryotes, protists (phyto- and protozooplankton) and metazooplankton - remained surprisingly stable throughout the experiment, without significant differences between fertilized waters and OUT stations (Mazzocchi et al., 2009; Thiele et al., 2012; Thiele et al., 2014). Given the low silicate concentration, diatoms accounted for only a small and approximately constant fraction $(<5 \%$ of autotrophic plankton biomass) (Thiele et al., 2014). Nanoflagellates (Phaeocystis-like species) and coccoid cells $(<10 \mu \mathrm{m})$ comprised over $50 \%$ of the phytoplankton biomass. The community comprised of bacterial and archaeal plankton was remarkably constant with similar numbers found at IN and OUT stations (Thiele et al., 2012). The zooplankton biomass was dominated by the large copepod Calanus simillimus $\left(\sim 30,000\right.$ individuals $\mathrm{m}^{-2}$ with a diurnal migration down to 
$200 \mathrm{~m}$ ) without significant differences in abundance between IN and OUT stations (Mazzocchi et al., 2009). In terms of iron cycling this stability suggests that recycling pathways probably remained unaltered. Secondly, the initial buildup of autotrophic and mixotrophic biomass was effectively controlled by grazing by large copepods (C. simillimus), whose numbers were themselves controlled by predation by the carnivorous amphipod Themisto gaudichaudii (Mazzocchi et al., 2009). Copepod incubation experiments showed that the grazing pressure was very high and the key factor controlling biomass during LOHAFEX. $C$. simillimus alone consumed on average 43 and $29 \%$ of total primary production per day, respectively, inside and outside the patch (González H.E., data not published). Third, there was no significant increase in vertical export of particulate organic carbon (POC) from the patch as nearly all sinking particles (mostly comprised of $C$. simillimus fecal pellets) were remineralized within the upper 100-150 m (Ebersbach et al., 2014; Martin et al., 2013).

By combining the evolution of biological and chemical parameters presented above we can divide the time evolution of the LOHAFEX experiment into three periods: 1) an initial phase during the first 12 days (up to station 137) that we labeled the growth phase; this was characterized by a steady increase of Chl-a concentrations and consumption of nutrients $\left.\left(\mathrm{NO}_{3}{ }^{-}, \mathrm{PO}_{4}{ }^{3-}\right) ; 2\right)$ a second phase from day 13 to day 24 (station 162) that we labeled the grazing phase; where nitrate consumption continued but Chl-a concentrations levelled off due to the grazing pressure exerted by large copepods; and 3) the last two weeks (days 25-37) of the experiment that were characterized (despite patch dilution) by a moderate decrease of the Chl-a concentration, stable nutrient concentrations, and relaxation of the grazing pressure by large copepods; we refer to this last stage as the dilution phase.

\section{Methods}

\subsection{Iron sampling}

Samples for iron measurements were obtained from one hydrocast the day before the first iron fertilization, followed by 13 casts collected at IN stations, and 3 casts collected at OUT stations (Table 1). Iron profiles were produced for the upper $200 \mathrm{~m}$ (dots in Fig. 2), although time restrictions and/or problems with bottle closure resulted in fewer shallower profiles. Since the fertilized patch did not remain static and its horizontal distribution was not homogeneous, sampling the center of the fertilized patch was challenging; therefore, concentrations presented in this paper might not represent maximum concentrations in the patch.

Seawater for trace metal analysis was collected in 8 Teflon-coated $5 \mathrm{~L}$ Go-Flo bottles mounted in an epoxy-coated aluminum frame (all from General Oceanics) and deployed on a Kevlar hydrowire. The bottle closure system was pressure triggered. After recovery, the bottles were immediately moved to an overpressurized particle-free plastic "bubble" where the head of the bottle was pressurized with $0.2 \mu \mathrm{m}$ filtered high purity nitrogen to allow seawater flow through Masterflex C-Flex tubes (Cole-Palmer) and collection in acid-cleaned low density polyethylene (LDPE) bottles (AZLON). DFe was sampled by online filtration through polycarbonate sterile capsules (Sartobran 300) fitted with $0.2 \mu \mathrm{m}$ filters.

\subsection{Iron analysis}

Ultrapure water was supplied by an Elix/Milli-Q apparatus (Millipore). Hydrochloric acid (Ultrapur, Merck) and ammonia (UltraTrace, Sigma) were of the maximum commercially available purity. Iron standards were prepared by dilution of an atomic absorption spectrometry standard solution (BDH) in Milli-Q water acidified to $\mathrm{pH}_{\mathrm{NBS}}=2.0(\mathrm{HCl}=0.01 \mathrm{M})$.

Two different analytical techniques were used to measure iron concentrations during LOHAFEX. Adsorptive Cathodic Stripping Voltammetry (AdCSV) was used onboard with the initial objective of contributing to the tracking of the patch. Back in the home lab, Inductively Coupled Plasma-Mass Spectroscopy (ICP-MS) measurements were carried out.

The electrochemical analyzer consisted of a 663 VA stand (Metrohm AG) with a hanging mercury drop electrode (HMDE), a glassy carbon counter electrode, and an $\mathrm{Ag} / \mathrm{AgCl}$ reference electrode, controlled by a $\mu$ Autolab voltammeter (Eco Chemie B.V.). The VA stand was insulated from ship rolling movements and vibrations by fixing it to a PVC platform that was suspended by an elastic rope from a second PVC platform; this second platform was firmly fixed to the work bench of a particle-free laminar hood placed in the bubble. Samples collected in $250 \mathrm{~mL}$ LDPE bottles were immediately acidified at pH 2.0 $(\mathrm{HCl} \sim 0.012 \mathrm{M})$, and $3 \times 10 \mathrm{~mL}$ aliquots of the sample were transferred immediately to $30 \mathrm{~mL}$ LDPE bottles (Nalgene) where they were allowed to equilibrate for $\sim 24 \mathrm{~h}$ in the presence of $30 \mu \mathrm{M}$ 2,3-dihydroxynaphthalene (DHN, Merck). The concentration of the Fe-DHN complex was determined by AdCSV (Laglera et al., 2013) immediately after neutralization to $\mathrm{pH} \sim 8.6 \pm 0.3$ by the addition of a $50 \%$ ammonia solution (the precise volume used depended on the aging of the ammonia solution) and $500 \mu \mathrm{L}$ of a combined solution of piperazine$N, N^{\prime}$-bis-(2-hydroxypropanesulfonic) acid (POPSO, Sigma-Aldrich) and potassium bromate (AnalaR, BDH). Contamination from iron in the combined solution was successfully removed by double equilibration for $24 \mathrm{~h}$ with a $\mathrm{MnO}_{2}$ suspension subsequently discarded by gravity filtration $(0.2 \mu \mathrm{m})$. Analyses were calibrated with internal iron additions. The accuracy of our AdCSV method was recently reassessed by comparison with analysis of UV digested samples and with the measurements generated by preconcentration in an oxine column, with flow injection analysis by chemiluminescence (Laglera et al., 2013). Iron contamination from all reagents was determined by tripling their individual concentration during the analysis of Milli-Q water, and was found to be $0.09 \mathrm{nM}$. Analysis of SAFE reference seawater (Johnson et al., 2007) gave concentrations of $0.86 \mathrm{nM}$ for sample D2 (consensus

Table 1

Summary of LOHAFEX stations sampled for the analysis of iron concentrations with corresponding mixed layer depth (MLD). Station 137 was intended to sample patch waters but our data indicates that it was located instead at the edge of the fertilized patch. The right hand column indicates the parameters related to iron partitioning and speciation. DFe: dissolved iron, $\mathrm{LFe}^{48 \mathrm{~h}}$ : iron leached after $48 \mathrm{~h}$ at $\mathrm{pH} 2.0$, TLFe: total leachable iron (see text for more details).

\begin{tabular}{|c|c|c|c|c|c|}
\hline Station & $\begin{array}{l}\text { Days after } \\
\text { 1st fertiliz. }\end{array}$ & $\begin{array}{l}\text { Days after } \\
\text { 2nd fertiliz. }\end{array}$ & Features & MLD (m) & $\begin{array}{l}\text { Fe parameters } \\
\text { sampled }\end{array}$ \\
\hline 114 & -1 & - & $\begin{array}{l}\text { Initial } \\
\text { conditions }\end{array}$ & 44 & $\mathrm{DFe}$ \\
\hline 121 & 2 & - & IN & 54 & $\mathrm{DFe}$ \\
\hline 126 & 3 & - & IN & - & $\mathrm{DFe}$ \\
\hline 129 & 4.4 & - & $\begin{array}{l}\text { N-S transect, } \\
\text { N edge }\end{array}$ & 36 & $\mathrm{DFe}$ \\
\hline 130 & 4.5 & - & $\begin{array}{l}\text { N-S transect, } \\
\text { N edge }\end{array}$ & 57 & $\mathrm{DFe}$ \\
\hline 132 & 4.9 & - & $\begin{array}{l}\text { N-S transect, } \\
\text { IN }\end{array}$ & 60 & $\mathrm{DFe}$ \\
\hline 135 & 9 & - & IN & 51 & $\mathrm{DFe}$ \\
\hline 137 & 12 & - & EDGE & 69 & DFe, $\mathrm{LFe}^{48 \mathrm{~h}}$ \\
\hline 139 & 14 & - & IN & 66 & $\begin{array}{l}\text { DFe, } \mathrm{LFe}^{48 \mathrm{~h}}, \\
\text { TLFe }\end{array}$ \\
\hline 146 & 16 & - & OUT & 38 & $\mathrm{DFe}, \mathrm{LFe}^{48 \mathrm{~h}}$ \\
\hline 148 & 18 & - & IN & 56 & $\begin{array}{l}\text { DFe, LFe }{ }^{48 h} \text {, } \\
\text { TLFe }\end{array}$ \\
\hline 160 & 23 & 2 & OUT & 61 & DFe, $\mathrm{LFe}^{48 \mathrm{~h}}$ \\
\hline 162 & 24 & 3 & IN & 46 & DFe, $\mathrm{LFe}^{48 \mathrm{~h}}$ \\
\hline 170 & 27 & 6 & IN & 48 & DFe, $\mathrm{LFe}^{48 \mathrm{~h}}$ \\
\hline 196 & 34 & 13 & IN & 81 & $\begin{array}{l}\text { DFe, } \mathrm{LFe}^{48 \mathrm{~h}}, \\
\text { TLFe }\end{array}$ \\
\hline 199 & 35 & 14 & OUT & 53 & $\begin{array}{l}\text { DFe, LFe }{ }^{48 ~ h}, \\
\text { TLFe }\end{array}$ \\
\hline 204 & 36 & 15 & IN & 85 & $\begin{array}{l}\text { DFe, } L_{F e} 48 \mathrm{~h} \\
\text { TLFe }\end{array}$ \\
\hline
\end{tabular}




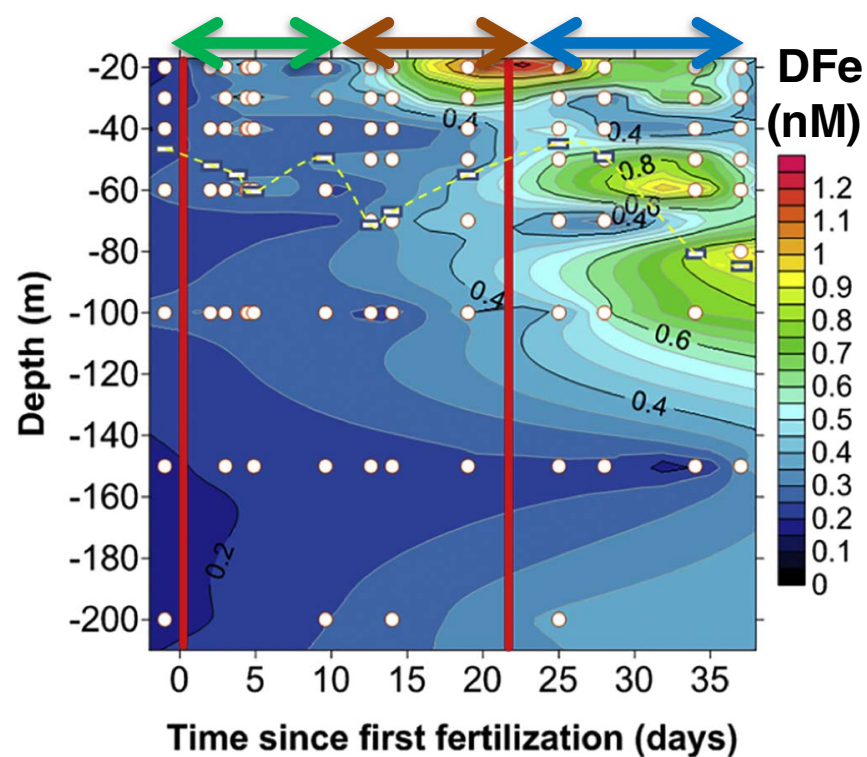

Fig. 2. Dissolved iron (DFe) concentrations $(<0.2 \mu \mathrm{m})$ in the upper $200 \mathrm{~m}$ of the water column of the fertilized patch during LOHAFEX. Units are nM. The red lines indicate the two fertilization events. The dashed line and the white rectangles indicate the MLD. The different stages of the experiment are indicated by the double arrows on the top of the panel (green: growth-stage, brown: grazing-stage and blue: dilution-stage). (For interpretation of the references to color in this figure legend, the reader is referred to the web version of this article.)

value $0.93 \pm 0.02 \mathrm{nM}$ ) and $0.093 \mathrm{nM}$ for sample $S$ (consensus value $0.093 \pm 0.008 \mathrm{nM}$ ). Due to time restrictions, duplicate and triplicate analyses were sometimes not measured when the analyses of the first aliquot gave a consistent profile (data shown without standard deviations in Table S1).

Iron concentrations after the cruise were determined by ICP-MS (PerkinElmer ELAN DRC-e) after pre-concentration using APDC/DDDC organic extraction (Tovar-Sánchez, 2012). Samples $(500 \mathrm{~mL})$ were acidified in the home lab with ultrapure $\mathrm{HCl}(30 \%)$ to a $\mathrm{pH}$ of 1.4 $(\mathrm{HCl} \sim 0.023 \mathrm{M})$ and stored for $\sim 2$ months prior to analysis. The accuracy of the analysis was established using two Seawater Reference Materials for Trace Elements (NASS-5 and CASS-4 CRM-CNRC, $3.71 \mathrm{nM}$ and $12.77 \mathrm{nM}$ respectively) with recoveries of $98 \%$ and $92 \%$ respectively. Extraction blanks were checked at regular intervals and prepared by extracting ultrapure water using exactly the same reagents and conditions as described for the samples. Blank signals were typically $<20 \%$ of the signals obtained from the analysis of the less concentrated cruise samples.

Because of time and analytical constraints, measurements on board were exclusively devoted to the analysis of unfiltered samples and isolated copepod fecal pellets after day 24 (see below). The DFe data over the whole length of the experiment was therefore obtained from a mix of on board AdCSV measurements up to day 24 (13 stations), and ICP-MS measurements in the home lab for samples from day 27 onwards (4 stations). The two methods gave consistent results with good agreement (Fig. S4). Both data sets were highly correlated $(n=15$; Pearson correlation: $\mathrm{r}=0.802, \mathrm{p}<0.001$ ) and a two-tailed $t$-test of data pairs did not show any differences between the methods (mean difference $=-0.0026 \pm 0.210 \mathrm{nM}, \mathrm{p}=0.963$ ).

\subsection{Iron fractions defined in this study}

As DFe profiles showed no prominent features or trends during the first week, we concluded that the study of iron cycling required the analysis of unfiltered samples. We collected unfiltered samples from 5 stations that were analyzed by ICP-MS analyses (similar to DFe: acidification with $\mathrm{HCl}$ to $\mathrm{pH} \sim 1.4$ for 2 months), in order to assess iron stocks well after both fertilizations took place (Table 1). We labeled this fraction "total leachable iron" (TLFe). It is representative of total iron in particles except for very refractory phases such as aluminosilicates and other compact crystalline structures (Powell et al., 1995; Raiswell et al., 1994) and large zooplankton (e.g.: Calanus copepods) that can escape being captured with Go-Flo bottles. In some previous works, this fraction has been labeled as "total dissolvable iron" (TDFe).

A novelty of this work is the use of an approach based on a two-step acid leaching treatment to define an additional third fraction: the iron leached in $48 \mathrm{~h}\left(\mathrm{LFe}^{48 \mathrm{~h}}\right)$ defined as the concentration of iron measured in unfiltered samples by voltammetry (Laglera et al., 2013) after acidification for $48 \mathrm{~h}$ at a $\mathrm{pH}$ of $2.0(\mathrm{HCl} \sim 0.012)$. Even though this treatment is definitely not sufficient to recover most of particulate iron (Lannuzel et al., 2011; Spokes and Jickells, 1996), this procedure was selected after observations that this protocol was strong enough to recover the iron contained in C. simillimus fecal pellets (see Section 3.3). The voltammetric method does not require particle removal by filtration or other physical processes to assess the concentration of particulate iron leached into the dissolved phase since particles do not interact with the working electrode. We prepared $10 \mathrm{~mL}$ triplicates from the original $250 \mathrm{~mL}$ sample bottle in order to assess the analytical precision. However, depending on time constraints and the consistency of the vertical profiles obtained after analysis of the first aliquot, some duplicates and triplicates were not processed (same criterion as that used for DFe data).

According to this analytical scheme we define the following particulate fractions (all denoted by an initial P):

$\mathrm{PLFe}^{48 \mathrm{~h}}=\mathrm{LFe}^{48 \mathrm{~h}}-\mathrm{DFe}$

$\mathrm{PLFe}^{48 \mathrm{~h}}$ represents the Fe leached from particles $>0.2 \mu \mathrm{m}$ in $48 \mathrm{~h}$ at $\mathrm{pH} 2.0$.

$\mathrm{PTLFe}=\mathrm{TLFe}-\mathrm{LFe}^{48 \mathrm{~h}}$

PTLFe represents the Fe leached from particles $>0.2 \mu \mathrm{m}$ after 2 months at $\mathrm{pH} 1.4$ that was not released by the $\mathrm{LFe}^{48 \mathrm{~h}}$ treatment.

$\mathrm{TLFe}=\mathrm{PTLFe}+\mathrm{PLFe}^{48 \mathrm{~h}}+\mathrm{DFe}$

The overall fractionation scheme and the nature of the particles that were targeted by each protocol are presented in Table 2. Section 4.2 provides bibliographic and empirical evidence that justify the assignments of the different types of Fe in oceanic particles to the different fractions shown in Table 2. We want to stress that adsorbed iron on particles is not included in the PTLFe fraction since it would have been desorbed by the $\mathrm{LFe}^{48 \mathrm{~h}}$ treatment and included in $\mathrm{PLFe}^{48 \mathrm{~h}}$.

All iron concentration values are presented in Table S1. No sample data have been discarded and dubious concentration values are underlined in Table S1.

Table 2

Description of the analytical procedure followed to determine the different operationallydefined Fe fractions presented in this work (see text for more details).

\begin{tabular}{|c|c|c|c|}
\hline $\begin{array}{l}\text { Analyzed } \\
\text { fraction }\end{array}$ & Filtration & $\begin{array}{l}\text { Acidification } \\
\text { protocol }\end{array}$ & Analytical method \\
\hline $\mathrm{DFe}$ & $0.2 \mu \mathrm{m}$ & $\begin{array}{l}24 \text { h; pH } 2.0 \\
2 \text { months; } \\
\text { pH } ~ 1.4\end{array}$ & $\begin{array}{l}\text { AdCSV } \\
\text { ICP-MS }\end{array}$ \\
\hline $\mathrm{LFe}^{48 \mathrm{~h}}$ & None & 48 h; pH 2.0 & AdCSV \\
\hline TLFe & None & $\begin{array}{l}2 \text { months; } \\
\mathrm{pH} \sim 1.4\end{array}$ & ICP-MS \\
\hline $\begin{array}{l}\text { Derived } \\
\quad \text { fraction }\end{array}$ & Definition & $\begin{array}{l}\text { Targeted } \\
\text { contributors }\end{array}$ & $\begin{array}{l}\text { Possible untargeted } \\
\text { contributors }\end{array}$ \\
\hline $\mathrm{PLFe}^{48 \mathrm{~h}}$ & $\mathrm{LFe}^{48 \mathrm{~h}}-\mathrm{DFe}$ & $\begin{array}{l}\text { Copepod fecal } \\
\text { pellets }\end{array}$ & $\begin{array}{l}\text { Adsorbed Fe, amorphous } \\
\text { Fe oxyhydroxides }\end{array}$ \\
\hline PTLFe & $\mathrm{TLFe}-\mathrm{LFe}^{48 \mathrm{~h}}$ & Biotic pool & $\begin{array}{l}\text { Airborne or glacial dust, } \\
\text { aged Fe oxyhydroxides }\end{array}$ \\
\hline
\end{tabular}




\subsection{Complementary onboard experiments to characterize the contribution of phytoplankton and fecal pellets to $\mathrm{LFe}^{48 \mathrm{~h}}$}

We used aliquots of non-axenic clonal phytoplankton cultures onboard and the acid leaching methods described in Section 2.3 to test iron leaching from three typical bloom forming species of the Southern Ocean: Phaeocystis cf. antarctica, Fragilariopsis kerguelensis and Pseudonitzschia lineola. In particular $P$. antarctica is representative of the flagellate community that was predominant in the experiment. A $50 \mathrm{~mL}$ volume of cell culture (in f/2 culture medium (Guillard and Ryther, 1962)) was filtered (0.45 $\mu \mathrm{m}$ pore size PVA filters) and rinsed with $3 \times 100 \mathrm{~mL}$ filtered seawater to remove traces of the $\mathrm{FeCl}_{3}$ and EDTA added to the culture medium (initially equimolar at $1.2 \times 10^{-5} \mathrm{M}$ ) that could interfere with the AdCSV measurement. Filters were moved immediately to a clean $30 \mathrm{~mL}$ LDPE container containing $20 \mathrm{~mL}$ of $0.2 \mu \mathrm{m}$ filtered seawater. Cells were resuspended by gently shaking the container for $2 \mathrm{~min}$. Next the filter was discarded and $3 \times 500 \mu \mathrm{L}$ of the suspension was transferred to $3 \times 30 \mathrm{~mL}$ LDPE containers (dilution 21 fold) each containing $10 \mathrm{~mL}$ of $0.22 \mu \mathrm{m}$ filtered seawater ([Fe]
$=0.32 \mathrm{nM}$ ). The concentration of iron leached from the cells was measured following the acidification protocol described above for $\mathrm{LFe}^{48 \mathrm{~h}}$. The remaining cell suspensions $(17.5 \mathrm{~mL}$ each) were stored for analysis of the TLFe fraction by ICP-MS back on land. The possibility of carry over of Fe or EDTA from the culture media was tested by immediate analysis of $10 \mathrm{~mL} 0.22 \mu \mathrm{m}$ filtered seawater spiked with $500 \mu \mathrm{L}$ of cell suspensions in the presence of $30 \mu \mathrm{M}$ DHN. These analyses resulted in iron concentrations close to the background concentration.

We also isolated the contribution to particulate iron by $C$. simillimus fecal pellets after the second fertilization. We used suspensions of freshly collected C. simillimus fecal pellets at six stations (160, 182 and 199 representing OUT stations and 170, 192 and 204 from IN stations). Copepods were collected from the upper $100 \mathrm{~m}$ layer with a WP2 vertical net equipped with a plastic $10 \mathrm{~L}$ non-filtering cod end. Immediately after sampling, $C$. simillimus individuals (mainly copepodites V and IV) were sorted and transferred to a clean Petri dish filled with clean filtered seawater. Fecal pellets were collected from the Petri dish with a Pasteur pipette and washed by two transfers in clean Petri dishes filled with the same clean filtered seawater. Finally, groups of 15
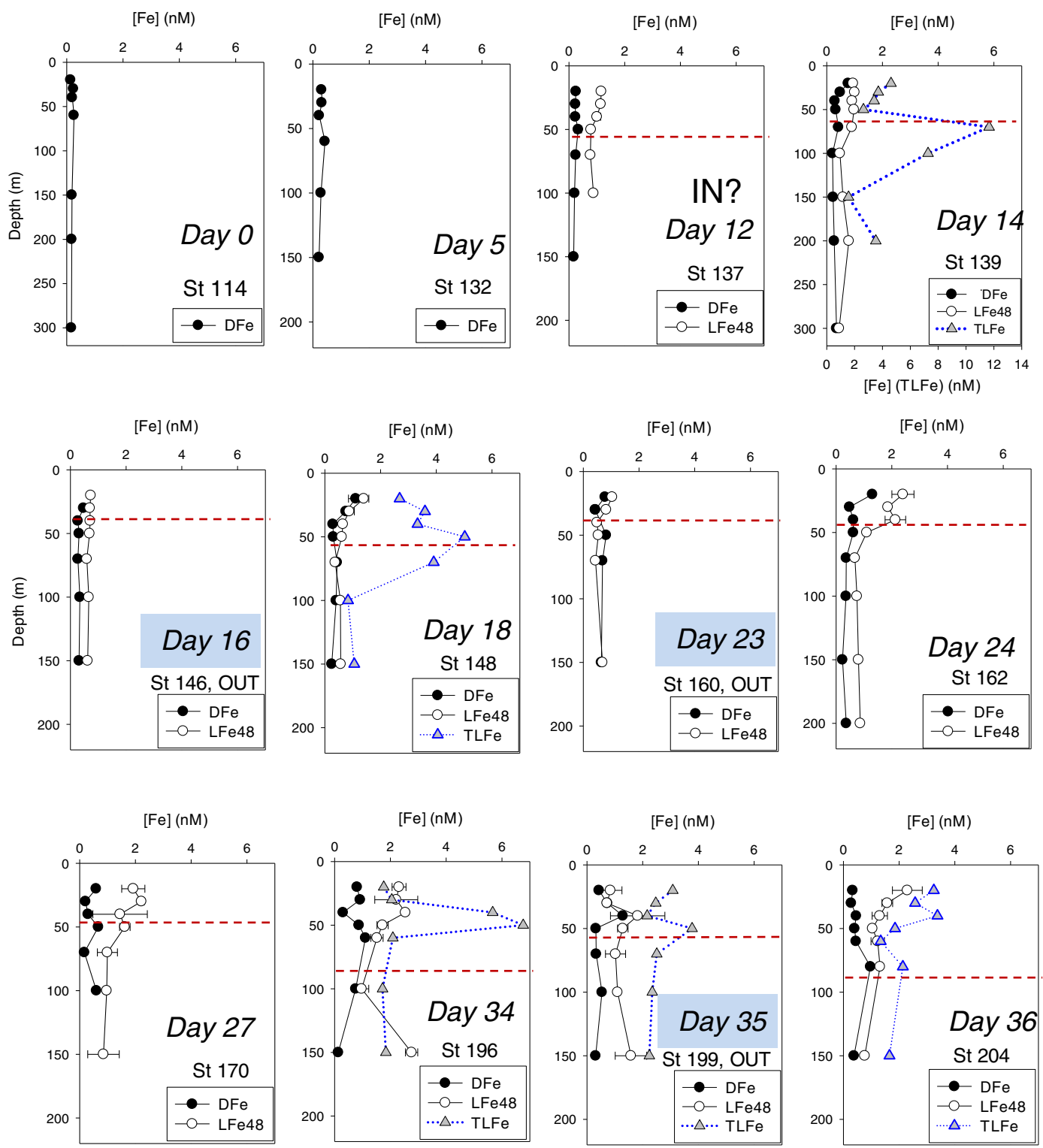

Fig. 3. Vertical distribution of the different iron fractions ( $\mathrm{DFe}, \mathrm{LFe}^{48 \mathrm{~h}}$ and TLFe) measured in the upper water column during the LOHAFEX experiment. The dashed red lines indicate the MLD (details in (Martin et al., 2013)). Note different scale for the TLFe concentrations at Station 139, day 14. Day 12 sampling started in fertilized waters, however, it is probable that the ship drifted from fertilized waters during its completion. (For interpretation of the references to color in this figure legend, the reader is referred to the web version of this article.) 
to 50 pellets were transferred to $30 \mathrm{~mL}$ LDPE bottles filled with $10 \mathrm{~mL}$ clean filtered seawater. All bottles received the $\mathrm{LFe}^{48 \mathrm{~h}}$ treatment before analysis onboard. Seven bottles containing fecal pellets from copepods captured at station 204 were stored to receive the TLFe treatment for comparison. All pellet iron concentrations are presented in Tables S2 and S3. The results from OUT station 182 are not reported because the zooplankton species collected at this station was not representative of the LOHAFEX community (large red copepods that did not belong to the genus Calanus). We processed and analyzed 31 samples (for a total of 1066 pellets) from copepods collected in fertilized waters, and 16 samples (693 pellets) from copepods collected in non-fertilized waters (Table S2). This sampling protocol allowed us to collect fecal pellets without contamination (blanks after manipulation are shown in Table S2) but at the cost of losing vertical resolution.

The kinetics of iron leaching at $\mathrm{pH} 2.0$ were determined by repeated analysis of $10 \mathrm{~mL}$ aliquots extracted from $500 \mathrm{~mL}$ of filtered $(0.2 \mu \mathrm{m})$ seawater and 70 C. simillimus fecal pellets (collected at station 204). The analysis was repeated approximately every $20 \mathrm{~min}$ until a stable concentration was obtained. The bottle was swirled every few minutes to homogenize its contents and pellets were allowed to settle for $2 \mathrm{~min}$ before the extraction of a new aliquot from the upper $2 \mathrm{~cm}$ of the bottle. Results are discussed in Section 3.3.

\subsection{Fecal pellet sampling for microscopic counting}

Fecal pellet concentrations and identifications were obtained from microscopy counts of samples collected with a CTD Rosette sampler at several discrete depths in the upper $500 \mathrm{~m}$ of the water column. For that purpose the entire contents of one Niskin bottle (12 L) was gently poured through gauze of $20 \mu \mathrm{m}$ mesh size. The retained particles were concentrated to a final volume of $50 \mathrm{~mL}$ and fixed with formaldehyde at a final concentration of $2 \%$. For the calculation of the contribution of fecal pellets to particulate iron we used data only from those stations sampled after the second fertilization: IN stations on days 24, 32 and 36 and OUT station 199 (day 35).

\section{Results}

\subsection{Dissolved iron during LOHAFEX}

The temporal evolution of DFe in the fertilized patch is shown in Fig. 2. The vertical profiles obtained at the most illustrative stations (except days 2 to 4 ) are plotted in Fig. 3. Prior to fertilization, DFe was low $(0.21 \pm 0.05 \mathrm{nM})$ and showed no trend with depth down to $300 \mathrm{~m}$. CLE-CSV analyses (van den Berg, 2006) of filtered samples in the presence of dihydroxynaphthalene showed that naturally occurring organic ligands were found in excess of DFe in all but two of the samples with ligand to DFe ratios in the range 0.7 to $19 \mathrm{nmol}$ ligand $(\mathrm{nmol} \mathrm{DFe})^{-1}$ (average $6.4 \pm 3.4 \mathrm{nmol}$ ligand $(\mathrm{nmol} \mathrm{DFe})^{-1}$, data not published).

During the first 12 days after fertilization (growth phase), DFe concentrations were constant down to $200 \mathrm{~m}$ (without any gradient across the ML) with values around $0.3 \mathrm{nM}$. This is surprising since our iron infusions were equivalent to an increment of $2.4 \mathrm{nM}$ throughout the ML. Vertical profiles during the grazing period (days 14 to 34 ) showed higher DFe concentrations near surface with an exponential decrease with depth in the upper $40 \mathrm{~m}$ of the water column (average DFe concentrations in the $0.5-0.7 \mathrm{nM}$ range with values up to $1.3 \mathrm{nM}$ at some stations). Again, this increment was not related to the second fertilization since high surface concentrations were found before day 21 . During the dilution phase (day 25 onwards) vertical profiles became less consistent with high concentrations scattered down to $100 \mathrm{~m}$ (average of $\sim 0.6 \mathrm{nM}$ with some values up to $0.9 \mathrm{nM}$ ).

The DFe distribution at the OUT stations was expected to remain close to pre-fertilization conditions, however, DFe vertical profiles showed variability similar to what was observed in fertilized waters.
DFe concentrations on day 16 were around $0.3 \mathrm{nM}$ except for the upper $30 \mathrm{~m}$ of the water column. The higher concentration at $20 \mathrm{~m}$ was flagged since we found a higher concentration in the unfiltered sample. Samples from days 23 and 35 showed a high degree of patchiness down to $150 \mathrm{~m}$, with two flagged values at $50 \mathrm{~m}$ and $70 \mathrm{~m}$ depth, respectively, on day 23. The flagged data will not be considered for further discussion.

\subsection{Particulate iron during LOHAFEX}

Vertical profiles of TLFe showed that particulate iron by far exceeded DFe (Fig. 3). TLFe concentrations during the grazing phase before the second fertilization were between 2 and $12 \mathrm{nM}$ and $2.5-5 \mathrm{nM}$ at days 14 and 18, respectively. In the last days of the experiment, TLFe concentrations decreased to values between 1.7 and $6.8 \mathrm{nM}$ and $0.8-2.3 \mathrm{nM}$, on days 34 and 37 , respectively. All TLFe profiles showed a well-defined bulge at 50-100 m with a maximum at, or slightly below, the MLD with concentrations several times higher than those found at $200 \mathrm{~m}$ (Fig. 3). This accumulation reached a maximum of $12 \mathrm{nM}$ at $100 \mathrm{~m}$ on day 14 before the second fertilization and was less pronounced towards the end of the experiment. At OUT station 199 (day 36, Fig. 3) a featureless TLFe profile was obtained with concentrations in the range $2.2-3.8 \mathrm{nM}$.

\subsection{Acidification experiments with C. simillimus fecal pellets and phytoplankton cells}

Iron leaching at pH 2.0 from C. simillimus fecal pellets increased for $10-15 \mathrm{~h}$ before leveling off at a concentration equivalent to a release of $\sim 0.039 \mathrm{nmol} \mathrm{Fe} \mathrm{pellet}^{-1}$ (Fig. S5). In order to estimate the percentage of iron recovered from fecal pellets with the $\mathrm{LFe}^{48 \mathrm{~h}}$ treatment, fecal pellets from C. simillimus collected on the same cast (day 37/station 204) were analyzed using both the $\mathrm{LFe}^{48 \mathrm{~h}}$ and the TLFe protocols (results in Tables S2 and S3). The concentrations for $\mathrm{LFe}^{48 \mathrm{~h}}$ (measured 9 suspensions containing 20 to 40 pellets each) and TLFe (measured in 7 suspensions containing 20 to 40 pellets each) were similar $\left(0.036 \pm 0.012 \mathrm{nmol} \mathrm{Fe} \mathrm{pellet}^{-1}\right.$ and $0.038 \pm 0.007 \mathrm{nmol} \mathrm{Fe} \mathrm{pellet}^{-1}$, respectively). The iron contained in fecal pellets released by $C$. simillimus captured after the second fertilization (all data in Table S2) was found to be significantly higher (Mann-Whitney test, $\mathrm{p}<0.001$ ) at 3 IN stations (days 24, 34 and 37) compared to that found at 2 OUT stations (days 23 and 36). Average iron concentrations were $0.041 \pm 0.019 \mathrm{nmol} \mathrm{Fe} \mathrm{pellet}^{-1}(\mathrm{n}=31$ samples containing 1066 pellets $)$ at the IN stations and $0.006 \pm 0.009 \mathrm{nmol} \mathrm{Fe} \mathrm{pellet}^{-1}$ at the OUT stations ( $n=15$ samples containing 693 pellets).

Comparison of the results obtained from the use of the two leaching protocols described above in cell suspensions of $P$. antarctica, $F$. kerguelensis and $P$. lineola showed that iron recovery after $48 \mathrm{~h}$ at $\mathrm{pH} 2.0$ was always a small fraction of the concentration recovered after 2 months at $\mathrm{pH}$ of 1.4. The $\mathrm{LFe}^{48 \mathrm{~h}}$ treatment recovered $2.7 \pm 1.0,4.3 \pm 0.6$ and $5.7 \pm 2.5 \mathrm{nM}$ $\mathrm{Fe}(\mathrm{n}=3$ each) for $P$. antarctica, $F$. kerguelensis and $P$. lineola respectively, whereas the TLFe treatment retrieved 1.31, 1.54 and $1.44 \mu \mathrm{M}$ Fe $(\mathrm{n}=3$ each) respectively. $\mathrm{LFe}^{48 \mathrm{~h}} / \mathrm{TLFe}$ ratios were $4.1,5.6$ and $7.6 \%$ for $P$. antarctica, F. kerguelensis and $P$. lineola respectively. These results are supported by onboard microscopic inspections of natural seawater samples before and after applying the $\mathrm{LFe}^{48 \mathrm{~h}}$ treatment that showed intact cells of several different phytoplankton species: the diatoms Navicula sp., Ephemera cf. planamembranacea, Ceratoneis closterium, Thalassionema nitzschioides, Corethron pennatum, the dinoflagellate Prorocentrum sp. the haptophyte Phaeocystis sp. and other unidentified flagellates (light micrographs of acidified cells in Fig. S6). These flagellates were predominant in the picoand nanoplankton biomass during LOHAFEX. As both treatments include any iron adsorbed on the cell wall, only intracellular iron and unidentified mineral phases contributed to PTLFe concentrations.

\section{4. $\mathrm{LFe}^{48 h}$ concentration during LOHAFEX}

The $\mathrm{LFe}^{48 \mathrm{~h}}$ fraction was sampled and measured from day 12 (end of 
the growth period) onwards (Fig. 3). $\mathrm{LFe}^{48 \mathrm{~h}}$ concentrations at IN stations before the second fertilization (days 12, 14, 18) ranged between $0.6 \mathrm{nM}$ and $1.1 \mathrm{nM}$ between $20 \mathrm{~m}$ and $70 \mathrm{~m}$ depth, and were only slightly lower below $70 \mathrm{~m}(0.5-0.9 \mathrm{nM}$, Figs. 3 and 4). In contrast to the evolution of the DFe and TLFe fractions, $\mathrm{LFe}^{48 \mathrm{~h}}$ concentrations clearly increased after the second fertilization (days 24, 27, 34 and 36) with concentrations ranging between $1.3 \mathrm{nM}$ and $2.8 \mathrm{nM}$ in the upper $70 \mathrm{~m}$ of the water column (a significant percentage of the $2.4 \mathrm{nM}$ nominal infusion). This increase was moderate below $80 \mathrm{~m}$ depth where concentrations ranged between $0.8 \mathrm{nM}$ and $1.3 \mathrm{nM}$ (with one exception of $2.8 \mathrm{nM}$ on day 34 at $150 \mathrm{~m}$ depth). Three $\mathrm{LFe}^{48 \mathrm{~h}}$ concentrations are flagged in Table S2 as those concentrations were slightly higher than their respective TLFe concentrations and may reflect contamination during subsampling.

At the OUT station on day 16 OUT, $\mathrm{LFe}^{48 \mathrm{~h}}$ concentrations ranged between $0.6 \mathrm{nM}$ and $0.8 \mathrm{nM}$ showing no trend with depth. Similar $\mathrm{LFe}^{48 \mathrm{~h}}$ concentrations were found at the OUT station on day 23 except for high values in the upper $30 \mathrm{~m}$ partially caused by higher DFe concentrations. The OUT station sampled on day 34 showed high patchiness down to $150 \mathrm{~m}$ depth with significantly higher concentrations $(0.7 \mathrm{nM}$ to $1.8 \mathrm{nM})$ that were not due to higher DFe concentrations.

\subsection{Calanus simillimus Fecal pellet distribution during LOHAFEX}

Microscopic counts showed that concentrations of pellets produced by large copepods showed a distinctive profile characterized by a maximum of $\sim 20$ pellets $\mathrm{L}^{-1}$ at $40 \mathrm{~m}$ depth in fertilized and unfertilized waters with decreasing concentrations down to $200 \mathrm{~m}$ depth and constant concentrations at approximately 5 pellets $\mathrm{L}^{-1}$ down to $500 \mathrm{~m}$ depth (Fig. S7) (Mazzocchi et al., 2009). Microscopic inspection revealed that in all samples, including those collected in the upper $20 \mathrm{~m}$, about half of the pellets appeared degraded, suggesting that they had been partially remineralized before they could be exported (M. Iversen, data not published).

\section{Discussion}

\subsection{DFe response to fertilizations during LOHAFEX}

The iron infusions during LOHAFEX were planned to increase DFe concentrations by one order of magnitude to $>2 \mathrm{nM}$ throughout the ML. However, 2 days after the initial iron fertilization only a minor increase of $\sim 0.1 \mathrm{nM}$ was observed (Figs. 2 and 3). Previous OIFs have shown that loss processes (such as uptake and precipitation) are characterized by time scales short enough to return DFe concentrations to pre-fertilization conditions in a period of 2-3 days (Bowie et al., 2001; Croot et al., 2001; Gordon et al., 1998; Kinugasa et al., 2005; Nishioka et al., 2009; Wells, 2003). Due to the scale of the LOHAFEX experiment, 2 to 3 days were required to fertilize $300 \mathrm{~km}^{2}$ and repositioning the ship in the center of the patch, hence the results of DFe measurements after the first fertilization were not completely unexpected.

Higher DFe concentrations were found at the surface from day 14 onwards and scattered high DFe concentrations down to $100 \mathrm{~m}$ deep were found from day 24 onwards. These were not created by the two fertilizations which occurred on days 0 and 21 (red lines in Fig. 2). Moreover, such high DFe concentrations were not the result of i) atmospheric inputs, since particulate iron did not show a parallel increase (Fig. 3) or ii) isopycnal diffusion, since no DFe gradients were observed at the bottom of the ML. It is therefore not possible to understand the DFe pattern without considering the major biological processes controlling carbon fluxes during LOHAFEX (see below).

\subsection{Type of particles contributing to the different particulate iron fractions}

$\mathrm{PLFe}^{48 \mathrm{~h}}$ and PTLFe concentrations can be estimated in Fig. 3 using Eqs. (1-3).
In seawater, iron dissolution kinetics of mineral particles under acidification can be modeled according to first-order kinetics where leaching rates and recoveries are a function of pH (Shi et al., 2011). Therefore, the presence of a single type of particles would translate into $\mathrm{PLFe}^{48 \mathrm{~h}}$ concentrations highly correlated to PTLFe concentrations with a slope that would be a function of the difference between these two treatments (time of exposure and $\mathrm{pH}$ ). During LOHAFEX, PTLFe and $\mathrm{PLFe}^{48 \mathrm{~h}}$ showed very different vertical and temporal patterns and consequently they did not correlate at all (Pearson correlation of data in Table S1: $\mathrm{r}=-0.09 ; \mathrm{p}=0.62 ; \mathrm{n}=33$ ); this supports the conclusion that each Fe fraction was formed by particles of a different nature.

The analytical performance of the two leaching protocols on cell cultures and C. simillimus fecal pellets proved that those pellets, the main component of the downward flux of POC (Martin et al., 2013), only contributed to the $\mathrm{PLFe}^{48 \mathrm{~h}}$ fraction whereas planktonic intracellular iron only contributed to the PTLFe fraction (according to the scheme presented in Table 2). However, there is still the uncertainty in the contribution of iron from mineral phases and freshly formed aggregates to each fraction since aging of colloidal iron in seawater makes it more refractory with respect to acidic treatments (Raiswell, 2011). Our PLFe ${ }^{48 \mathrm{~h}}$ profiles after the second fertilization (Figs. 3 and 4) show the same features as the vertical distribution of fecal pellet abundances determined by UVP (Martin et al., 2013), multinet hauls (González, data not published), and counts of copepod fecal pellets from large volume filtrations (Fig. S7). In all cases, higher concentrations of $\mathrm{PLFe}^{48 \mathrm{~h}}$ were found in the upper 80-100 $\mathrm{m}$ of the water column with a maximum at $\sim 50 \mathrm{~m}$ (1.5 to $2.2 \mathrm{nM}$ ) and significantly lower values at depths below $100 \mathrm{~m}(0.3-0.5 \mathrm{nM})$. We also estimated the pellet contribution to $\mathrm{PLFe}^{48 \mathrm{~h}}$ concentrations after the second fertilization in the upper water column from the average vertical distribution of fecal pellets during the last week of the experiment and the averaged iron content per copepod fecal pellet at IN stations (Fig. 5). Although those samples were taken from different casts and sampling equipment, the similarity between the magnitude and shape of the profiles obtained by the two different approaches is remarkable, further supporting our hypothesis that fecal pellets excreted by $C$. simillimus were the main contributor to $\mathrm{PLFe}^{48 \mathrm{~h}}$ in fertilized waters. For unfertilized water, concentrations of $\mathrm{PLFe}^{48 \mathrm{~h}}$ were very low down to $200 \mathrm{~m}$ despite similar copepod fecal pellet concentrations to those of the fertilized waters at all depths (Fig. S8). Further support for the hypothesis that PLFe ${ }^{48 \mathrm{~h}}$ was a valid proxy for the estimation of the contribution of copepod fecal

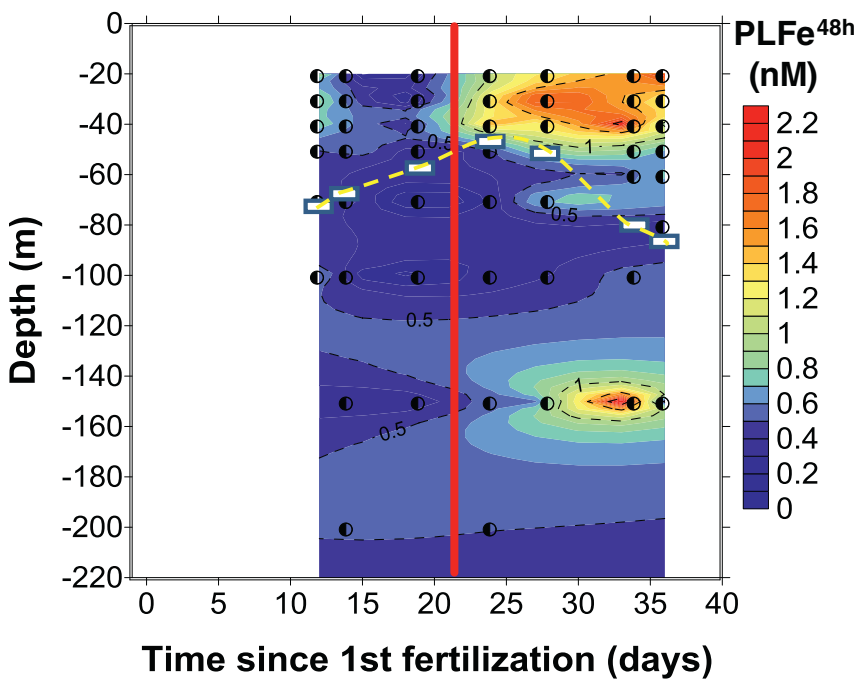

Fig. 4. Temporal evolution of particulate iron leached in $48 \mathrm{~h}$ at $\mathrm{pH} 2$ $\left(\mathrm{PLFe}^{48 \mathrm{~h}}=\mathrm{LFe}^{48 \mathrm{~h}}-\mathrm{DFe}\right.$ ) in the upper water column of the fertilized patch (concentrations are given in $\mathrm{nM}$ ). The dashed line and the white rectangles indicate the MLD. The red line indicates the second fertilization event. (For interpretation of the references to color in this figure legend, the reader is referred to the web version of this article.) 


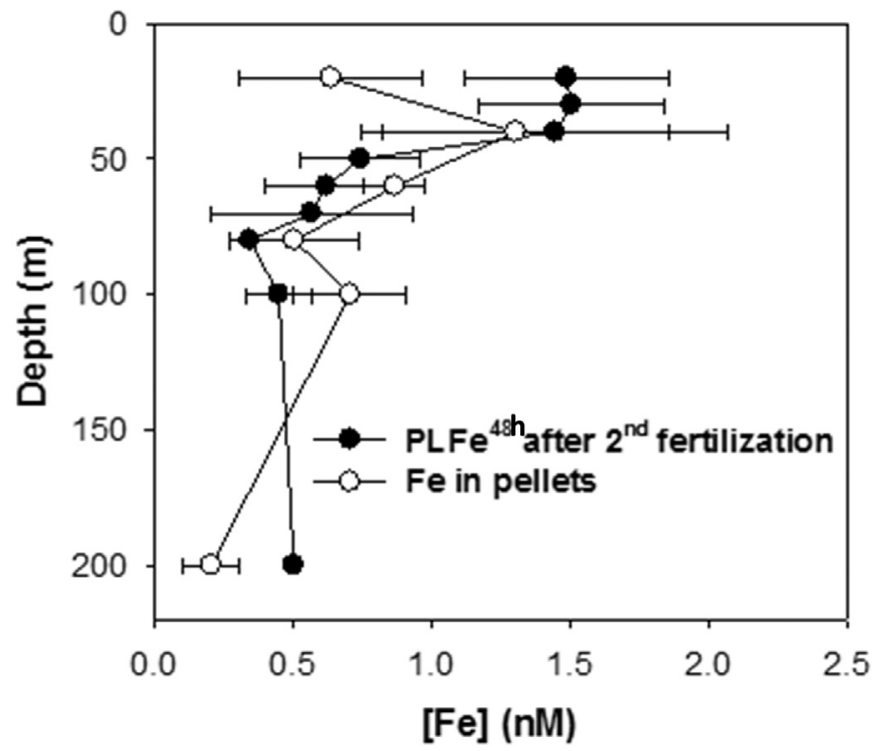

Fig. 5. Vertical distributions of particulate iron after the second fertilization calculated following two different approaches. Solid symbols: $\mathrm{PLFe}^{48 \mathrm{~h}}$ averaged for days 24, 27, 34 and 36 (stations 162, 170, 196 and 204). Open symbols: Concentration of iron contained in copepod fecal pellets estimated from the average content of iron in fecal pellets in fertilized waters $\left(0.041 \mathrm{nmol} \mathrm{Fe} \mathrm{pellet}{ }^{-1}\right)$ multiplied by the number of pellets $\mathrm{L}^{-1}$ measured on days 30, 34 and 36 (stations 192, 199 and 204).

pellet to particulate iron in LOHAFEX conditions can be found in Section 4.3 and in the SI file where we provide a section with arguments based on previous literature.

Vertical profiles of the PTLFe fraction on days 14, 18 and 34 (Fig. 3) showed clear maxima at 50-100 $\mathrm{m}$ that were not correlated with Chl-a (Fig. 1B), fecal pellets (Fig. S7), transmission (proxy for POC) or fluorescence (a proxy for biomass/chlorophyll) profiles (Fig. S9 for profiles at day 14, station 139). This lack of correlation suggests that at least during the grazing period a substantial percentage of PTLFe in between $50 \mathrm{~m}$ and $100 \mathrm{~m}$ depth could have come mostly from abiotic particles. Unfortunately, since we did not collect unfiltered samples in the 2 weeks following both fertilizations, we cannot determine if stabilized (long-aged) oxyhydroxides persisting from the fertilizations could have contributed to the PTLFe pool.

It should be stressed that the unique conditions during LOHAFEX, specially the low contribution of the other two main zooplankton groups in open waters of the Southern Ocean, namely salps and euphausiacea (krill), facilitated the interpretation of our results. Recent work on the fecal depositions of salps (unlike copepods, a filter-feeder) has shown that the $\mathrm{LFe}^{48 \mathrm{~h}}$ treatment was too weak to recover more than a minor percentage of their iron content (Cabanes et al., 2017), possibly because salps do not crush their food in contrast to copepods and euphausiacea.

\subsection{Integrated iron stocks in the different fractions during LOHAFEX}

Understanding the role of biological processes in iron cycling during the experiment is impaired by the patchiness shown by the DFe and PTLFe vertical profiles. We tried to overcome this problem by calculating standing stocks (values integrated over the upper $80 \mathrm{~m}$ ) of all iron fractions defined in this study (Table 3). The standing stock of a single specific chemical or biological species is often calculated by integrating its concentration down to the ML depth. This approach was well-suited for the study of iron cycling during other OIFs such as the SOIREE experiment since DFe and many other parameters showed strong gradients across the MLD (Bowie et al., 2001). However, during LOHAFEX, Chl-a (Fig. 1A), nutrients and POC (data not shown), TLFe (Fig. 3) and DFe (Fig. 2) showed high concentrations and features that often extended well below the MLD. Conversely, concentrations of PTLFe, PLFe ${ }^{48 \mathrm{~h}}$, Chl-a and POC showed sharp gradients located at around $80 \mathrm{~m}$ independently of the MLD throughout the duration of the experiment (Figs. 2 and 3). Furthermore, iron per pellet concentrations were measured from copepods captured via multinet hauls from the upper $100 \mathrm{~m}$, hence, we do not have information on possible variations of the iron content per pellet as a function of depth. Since our priority was to resolve the effect of biological processes in iron recycling, we used $80 \mathrm{~m}$, the deeper limit of the Chl-a increase during most of the experiment, as the depth of integration for the estimation of standing stocks.

The evolution throughout the experiment of the DFe, PLFe ${ }^{48}$ and PTLFe standing stocks in the upper $80 \mathrm{~m}$ of the water column and their contribution to TLFe (when determined) is listed in Table 3.

The standing stock of DFe was nearly constant at $\sim 20-25 \mu \mathrm{mol} \mathrm{Fe}$ $\mathrm{m}^{-2}$ during the growth phase but it suddenly doubled to $\sim 40-70 \mu \mathrm{mol} \mathrm{Fe} \mathrm{m}^{-2}$ from day 14 onwards (start of the grazing period) and remained at that level for the rest of the experiment (Table S2). This increase, previous to the second fertilization, was coincident with the maximum of Chl-a concentrations. At OUT stations, where grazing by large copepods was similar, DFe standing stocks showed a similar increase to $44 \mu \mathrm{mol} \mathrm{Fe} \mathrm{m}^{-2}$ on day 35 .

The PLFe ${ }^{48 \mathrm{~h}}$ standing stock was low during the week preceding the second fertilization at $\sim 20-40 \mu \mathrm{mol} \mathrm{Fe} \mathrm{m}^{-2}$ in fertilized waters and $<10 \mu \mathrm{mol} \mathrm{Fe} \mathrm{m}{ }^{-2}$ in OUT stations (Table 3, area in between diamonds and circles in Fig. 6). After day 21, the PLFe ${ }^{48 \mathrm{~h}}$ standing stock increased nearly 3 fold in fertilized waters and remained high until the end of the experiment at $70-90 \mu \mathrm{mol} \mathrm{Fe} \mathrm{m}^{-2}$ (average $81 \pm 15 \mu \mathrm{mol} \mathrm{Fe} \mathrm{m}{ }^{-2}$ ). This increase of $\sim 50 \mu \mathrm{mol} \mathrm{Fe}^{-2}$, is equivalent to $\sim 40 \%$ of the amount of iron infused $\left(120 \mu \mathrm{mol} \mathrm{Fe} \mathrm{m}^{-2}\right)$. The PLFe ${ }^{48 \mathrm{~h}}$ standing stock in the OUT station sampled on day 35 was $42 \mu \mathrm{mol} \mathrm{Fe} \mathrm{m}^{-2}$, a substantial increase with respect to previous OUT stations but approximately half of the $\mathrm{PLFe}^{48 \mathrm{~h}}$ standing stock found on day 36 in fertilized waters.

This general increase of PLFe ${ }^{48 \mathrm{~h}}$ standing stocks after day 21 can be partially explained by the concurrent increase of copepod fecal pellet standing stocks (Fig. 7). At IN stations, we counted

Table 3

Standing stocks (all in $\mu \mathrm{mol} \mathrm{m}{ }^{-2}$ ) of total leachable iron (TLFe), total particulate leachable iron (PTLFe), particulate leachable iron in $48 \mathrm{~h}\left(\mathrm{PLFe}^{48 \mathrm{~h}}\right)$ and DFe at selected stations during LOHAFEX. Values were integrated for the upper $80 \mathrm{~m}$ of the water column.

The percentages represent the contribution of that fraction to TLFe. Estimated iron contained in C. simillimus fecal pellets (Fe pellets) was calculated from the microscopic counts of fecal pellets in the water column multiplied by the iron concentration in pellets determined during the cruise $\left(0.041 \mathrm{nmol}\right.$ pellet $^{-1}$ IN stations and $0.006 \mathrm{nmol}^{\text {pellet }}{ }^{-1}$ OUT stations). n.s.: not sampled.

\begin{tabular}{|c|c|c|c|c|c|c|c|c|c|}
\hline Station & Day & TLFe & \multicolumn{2}{|c|}{ PTLFe } & \multicolumn{2}{|c|}{$\mathrm{PLFe}^{48 \mathrm{~h}}$} & \multicolumn{2}{|l|}{$\mathrm{DFe}$} & Fe pellets \\
\hline St 114 & 0 & n.s. & - & & n.s. & & 17 & & \\
\hline St 121 & 2 & n.s. & - & & n.s. & & 4 & & \\
\hline St 126 & 3 & n.s. & - & & n.s. & & 24 & & \\
\hline St 129 & 4.4 & n.s. & - & & n.s. & & 35 & & \\
\hline St 131 & 4.5 & n.s. & - & & n.s. & & 25 & & \\
\hline St 132 & 4.9 & n.s. & - & & n.s. & & 26 & & \\
\hline St 135 & 10 & n.s. & - & & n.s. & & 21 & & \\
\hline St 137 & 13 & n.s. & - & & 40 & & 20 & & \\
\hline St 139 & 14 & 437 & 360 & $83 \%$ & 34 & $8 \%$ & 39 & $9 \%$ & \\
\hline St 148 & 18 & 274 & 210 & $75 \%$ & 16 & $6 \%$ & 51 & $19 \%$ & \\
\hline St 162 & 24 & n.s. & - & & 70 & & 60 & & 73 \\
\hline St 170 & 27 & n.s. & - & & 94 & & 36 & & \\
\hline St 192 & 30 & n.s. & & & n.s. & & n.s. & & 67 \\
\hline St 196 & 34 & 237 & 82 & $35 \%$ & 85 & $36 \%$ & 69.6 & $29 \%$ & \\
\hline St 204 & 36 & 201 & 72 & $36 \%$ & 85.5 & $43 \%$ & 42.8 & $21 \%$ & 60 \\
\hline \multicolumn{10}{|c|}{ OUT stations } \\
\hline St 146 & 17 & n.s. & - & & 7.3 & & 48 & & 5.5 \\
\hline St 160 & 23 & n.s. & - & & 3.1 & & 56 & & \\
\hline St 199 & 35 & 229 & 140 & $62 \%$ & 42 & $18 \%$ & 44 & $19 \%$ & 12 \\
\hline
\end{tabular}




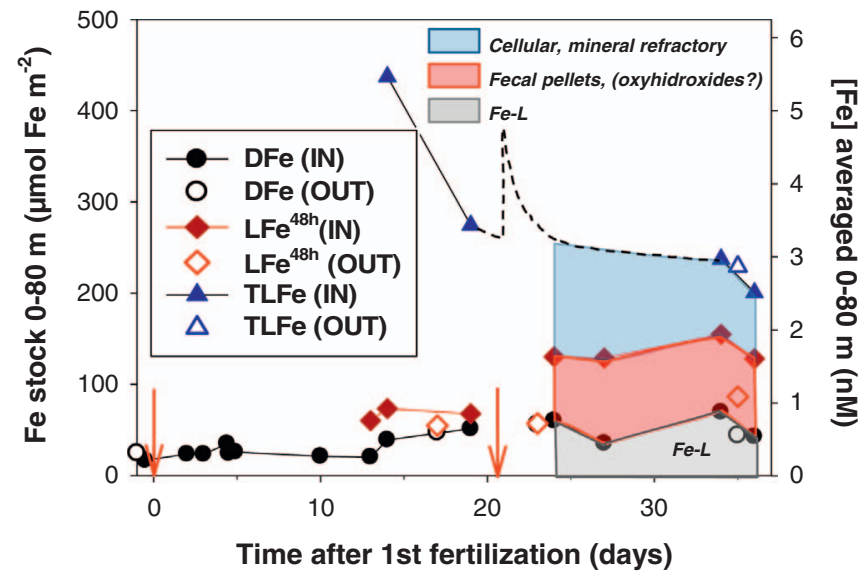

Fig. 6. Temporal evolution of the standing stocks (left Y-axis) of the different iron fractions (DFe, $\mathrm{LFe}^{48 \mathrm{~h}}$ and TLFe), measured during LOHAFEX and integrated over the upper $80 \mathrm{~m}$ of the water column. The right Y-axis shows the average concentrations in the upper $80 \mathrm{~m}$ of the water column estimated from the standing stocks in order to facilitate comparison with the iron profiles shown in Fig. 3.The red arrows indicate the two fertilization events. The dashed line is an estimate of the evolution of the TLFe stock from days 18 to 34 including the addition of $\sim 120 \mu \mathrm{mol} \mathrm{Fe} \mathrm{m}^{-2}$ during the second fertilization. The gray and red shaded areas show the evolution of the DFe and $\mathrm{PLFe}^{48 \mathrm{~h}}$ stocks and the blue shaded area is an estimate of the PTLFe stock during the last two weeks of the experiment. (For interpretation of the references to color in this figure legend, the reader is referred to the web version of this article.)

$920 \pm 380$ fecal pellet $\mathrm{m}^{-2}$ before the second fertilization $(\mathrm{n}=3)$ and $1600 \pm 160$ fecal pellet $\mathrm{m}^{-2}$, a 1.7 fold increase, thereafter $(\mathrm{n}=3)$. Copepod fecal pellet standing stocks at OUT stations showed a 2.2 fold increase with stocks of 800-900 and 1900 fecal pellet $\mathrm{m}^{-2}$ before and after the second fertilization, respectively (Fig. 7). Since we determined iron per C. simillimus fecal pellet after the second fertilization in fertilized and unfertilized waters, we can estimate the contribution of copepod fecal pellet standing stocks to particulate iron stocks (Table 3). We calculated fecal pellet iron standing stocks of 73, 67, $60 \mu \mathrm{mol} \mathrm{Fe} \mathrm{m}{ }^{-2}$ (average $67 \pm 7 \mu \mathrm{mol} \mathrm{Fe} \mathrm{m}^{-2}$ ) for IN stations and $12 \mu \mathrm{mol} \mathrm{Fe} \mathrm{m}^{-2}$ for the OUT station on day 35, respectively (Table 3). Therefore, we could estimate that $82 \%$ of the $\mathrm{PLFe}^{48 \mathrm{~h}}$ standing stock in fertilized waters was comprised of iron-rich C. simillimus fecal pellets. In the OUT station sampled on day 35 this percentage would be significantly lower at $26 \%$.

We observed that the PTLFe standing stock steadily decreased as the second half of the experiment progressed from $\sim 360 \mu \mathrm{mol} \mathrm{Fe} \mathrm{m}^{-2}$ on day 14 to $\sim 70-80 \mu \mathrm{mol} \mathrm{Fe} \mathrm{m}^{-2}$ at the end of the experiment, equivalent to a shift from 4.5 to $1 \mathrm{nM}$ (Table 3, Fig. 6). This decrease of ap-

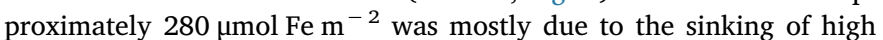
concentrations of abiotic (not associated to POC) iron found at the bottom of the ML depth on days 14 and 18 (day 14 profile discussed in Section 4.2). The PTLFe loss was partially compensated by the increase in the $\mathrm{PLFe}^{48 \mathrm{~h}}$ fraction. As a result, TLFe, the overall stock, showed low

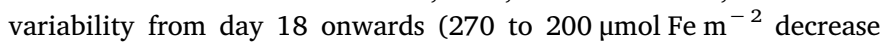
over 19 days) which is consistent with the reduced export of POC observed during the experiment (Martin et al., 2013).

Based on the apparent stability of TLFe stocks after day $18(n=3)$, the lack of impact from the second fertilization on the DFe stock, the low POC export (Martin et al., 2013) and the stability of $\mathrm{LFe}^{48 \mathrm{~h}}$ and DFe stocks after the second fertilization $(n=4)$, we conclude that the dashed line in Fig. 6 represents a valid approximation of the TLFe budget during the dilution stage of the experiment (the peak reproduces approximately the $120 \mu \mathrm{mol} \mathrm{m}^{-2}$ infusion on day 21). Thus, the gray, red and blue shaded areas in Fig. 6 show the time evolution of the DFe, PLFe ${ }^{48 \mathrm{~h}}$ stocks and an estimate of the PTLFe stock. Our data show that, despite the ongoing biological, physical and chemical processes during the last stage of the experiment, the contributions to the overall iron stock of the DFe, $\mathrm{PLFe}^{48 \mathrm{~h}}$, and PTLFe fractions were in the region of 25,40 , and $35 \%$, respectively.

\subsection{Role of primary producers on iron cycling}

It is possible to produce a rough estimate of the biological contribution to PTLFe concentrations and iron cycling from our knowledge of the primary producer community and of iron quotas in flagellates during OIF experiments.

The Fe: $\mathrm{C}$ ratio in plankton has been studied via controlled incubations and it has been shown to be a function of many variables including the environmental availability of iron (Twining and Baines, 2013) and plankton composition, increasing with smaller cell volume (Schmidt and Hutchins, 1999). During the OIF SOIREE the average Fe:C ratio was $2.7 \pm 1.4 \mu \mathrm{mol} \mathrm{Fe}(\mathrm{mol} \mathrm{C})^{-1}$ (Abraham et al., 2000; Maldonado et al., 2001) and iron quotas were higher in flagellates than in diatoms, reaching $48 \mu \mathrm{mol} \mathrm{Fe}(\mathrm{mol} \mathrm{C})^{-1}$ in flagellates upon fertilization (Twining et al., 2004). During SOFeX, Fe:C ratios in heterotrophic flagellates increased from 14 to a similar ratio of $40 \mu \mathrm{mol} \mathrm{Fe}$ $(\mathrm{mol} \mathrm{C})^{-1}$ after alleviation of iron limitation (Twining et al., 2004). Due to their ability to ingest particles by phagotrophy, Fe:C ratios as high as $150 \mu \mathrm{mol} \mathrm{Fe} \mathrm{(mol} \mathrm{C)})^{-1}$ were obtained in flagellate incubations fed exclusively with iron colloids (Maranger et al., 1998).

POC standing stocks in the upper $80 \mathrm{~m}$ of the water column at IN stations were in the range of $8-10 \mathrm{~g} \mathrm{C} \mathrm{m}^{-2}\left(\sim 0.7-0.9 \mathrm{~mol} \mathrm{C} \mathrm{m}^{-2}\right)$ throughout LOHAFEX. Using typical and maximum flagellate iron quotas observed in previous OIFs (40 and $150 \mu \mathrm{mol} \mathrm{Fe} \mathrm{(mol} \mathrm{C)})^{-1}$ respectively) (Maranger et al., 1998; Twining et al., 2004) we can estimate the contribution of phytoplankton to the PTLFe standing stock. That contribution can be estimated at $\sim 30-40 \mu \mathrm{mol} \mathrm{Fe} \mathrm{m}^{-2}$ and should not have exceeded $\sim 140 \mu \mathrm{mol} \mathrm{Fe} \mathrm{m}^{-2}$. PTLFe stocks determined from day 18 onwards (Table 3) were in the range of $70-210 \mu \mathrm{mol} \mathrm{Fe} \mathrm{m}^{-2}$, indicating that intracellular iron was probably a significant contributor to PTLFe iron stocks (at least $40 \%$ towards the end of the experiment). For comparison, in the diatom dominated SOIREE, biogenic Fe was estimated to represent only $\sim 9 \%$ of the particulate Fe pool (Bowie et al., 2001).

We also estimated the net assimilation of iron required for the observed biomass increment (estimated by the net community production, NCP). NCP ranged from zero to $0.070 \mathrm{~mol} \mathrm{C} \mathrm{m}^{-2}$ day $^{-1}$ (higher values during the grazing period) and averaged $0.021 \mathrm{~mol} \mathrm{C} \mathrm{m}^{-2}$ day $^{-1}$ throughout the experiment (Martin et al., 2013). Using the expected and upper estimates for the plankton $\mathrm{Fe}: \mathrm{C}$ ratio given above, the daily accumulation of iron by plankton was highest during the grazing phase at $\sim 3-11 \mu \mathrm{mol} \mathrm{Fe} \mathrm{m}{ }^{-2}$ day $^{-1}$ with an average daily uptake of $\sim 0.8-3 \mu \mathrm{mol} \mathrm{Fe} \mathrm{m}^{-2}$ day $^{-1}$. Thus, the daily iron requirement for NCP was small but integrated throughout the period of net growth (25 continuous days with NCP $>0$, Fig. 1B) ranged between 20 and

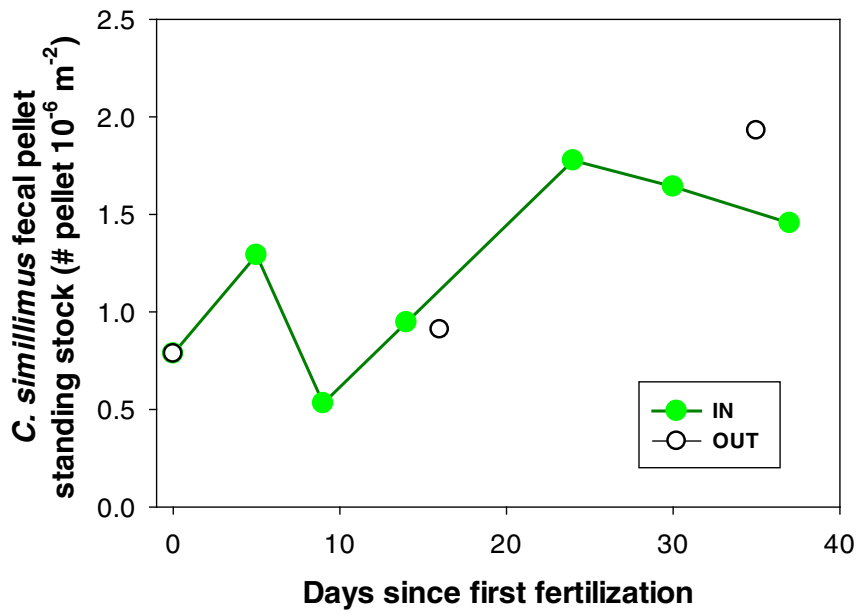

Fig. 7. Temporal evolution of the standing stocks of $C$. simillimus fecal pellets in the upper $80 \mathrm{~m}$ of the water column during LOHAFEX. 
$75 \mu \mathrm{mol} \mathrm{Fe} \mathrm{m}^{-2}$, which is an iron demand similar to the DFe and $\mathrm{LFe}^{48 \mathrm{~h}}$ stocks (Table S2). The relative stability of DFe and LFe ${ }^{48 \mathrm{~h}}$ stocks after day 21(Fig. 6 and Table 3) can only be explained through recycling processes.

\subsection{Flagellate phagotrophy and copepod grazing control of iron cycling}

In this section we will explore how the composition of the plankton community and grazing by copepods, the top-down biological process controlling carbon cycling during LOHAFEX, can help with interpreting our observations about iron cycling.

The explanation for the evolution of iron partitioning may be due to the large numbers of mixotrophic flagellates (mainly prymnesiophytes such as Phaeocystis) found during LOHAFEX at IN and OUT stations (Mazzocchi et al., 2009; Thiele et al., 2014) and to their ability to ingest colloidal iron via phagotrophy (Barbeau et al., 1996). On the other hand, the feeding behavior of copepods which is characterized by inefficient ("sloppy") feeding and coprophagy (ingestion of fecal material) may play important roles (see below for a detailed description of both processes). Both processes reduce drastically the sinking rates of POC (including fecal pellets), favoring its remineralization in shallow waters.

Remineralization of planktonic iron by zooplankton grazing has been described for krill (Tovar-Sanchez et al., 2007), salps (Cabanes et al., 2017) and copepods in studies more closely related to LOHAFEX conditions (Hutchins and Bruland, 1994; Sarthou et al., 2008; Sato et al., 2007). Efficient biological remineralization of iron by grazers was invoked as the possible reason behind the resilience shown by the SOIREE patch 42 days after its initialization (Bowie et al., 2001). The longevity of the LOHAFEX bloom (many weeks), the evidence of recycling processes in the upper $80 \mathrm{~m}$, the low export of POC below $100-150 \mathrm{~m}$ and our knowledge that copepod grazing controlled phytoplankton biomass, all point to the rapid recycling of iron in copepod fecal pellets within or very close to the euphotic zone in such a way that it could be made available for primary producers.

Since copepods use their mouthparts to capture and crush their prey before ingestion, their carbon uptake is highly inefficient (sloppy feeding). As a consequence, as much as $50 \%$ of the carbon content in food is immediately released as DOC and an additional $\sim 6 \%$ is quickly leaked as DOC from fecal pellets upon their release (Møller et al., 2003). Sloppy feeding is thus the fastest possible way to recycle iron from phytoplankton (and other ingested particles such as fecal pellets) into DFe. Copepod grazing on phytoplankton such as flagellates produces fecal pellets that sink at slower rates than those produced after ingestion of diatoms (Feinberg and Dam, 1998). Fecal material serves as a growth substrate for bacteria (González and Biddanda, 1990; Jacobsen and Azam, 1984). Therefore, copepod fecal pellets after a flagellate diet undergo shallower microbial degradation than those produced from diatoms (Hansen et al., 1996). In addition, copepods not only prey on smaller plankton but reprocess their own fecal material via coprophagy (pellet ingestion), coprorhexy (pellet fragmentation) or coprochaly (pellet peeling) (Gonzalez and Smetacek, 1994; Iversen and Poulsen, 2007; Jansen et al., 2007; Noji et al., 1991).

Incubations have shown that pellets are usually fragmented by coprorhexy on a time scale of hours after their production, before microbiota are able to cause significant degradation (Lampitt et al., 1990). Moreover, there is a synergistic effect; pellet fragmentation results in smaller pellet fragments with larger surface to volume ratios facilitating microbial remineralization in the upper layer (Feinberg and Dam, 1998).

All the processes described above and fluxes among the iron fractions defined in this study, are summarized in Fig. 8. Uptake of DFe by phytoplankton would transfer DFe to PTLFe, while phagotrophy by flagellates could transfer $\mathrm{PLFe}^{48 \mathrm{~h}}$ (as colloidal Fe oxyhydroxides) to PTLFe. Copepod grazing results in several processes: phytoplankton consumption transfers PTLFe from phytoplankton to zooplankton and may also transfer PTLFe to DFe via "sloppy feeding". Fecal pellet production leads to an increase of the PLFe ${ }^{48 \mathrm{~h}}$ compartment, while coprophagy leads to recycling of $\mathrm{PLFe}^{48 \mathrm{~h}}$ into the DFe compartment. Bacterial remineralization of fecal pellets transfers $\mathrm{PLFe}^{48 \mathrm{~h}}$ to DFe.

Each route impacts iron remineralization in a different style. Microbial degradation is a slow and steady process whereas sloppy feeding on plankton or during coprophagy and coprorhexy could produce localized bursts of DFe. An increase in copepod grazing on their own fecal products is consistent with the observed increase in DFe stocks and the increase in scattered high DFe concentrations.

\subsection{Dynamic iron partitioning and iron recycling during LOHAFEX}

Despite the high fecal pellet production in the upper $100 \mathrm{~m}$ (Martin et al., 2013, Gonzalez, data not published), the vertical flux of POC at $100 \mathrm{~m}$ was $<30 \%$ of the daily NCP and $<5 \%$ of the daily primary production on average (Martin et al., 2013). The rapid degradation of sinking particles (at both IN and OUT stations) indicates a fast turnover of POC in the upper $100 \mathrm{~m}$ and would result in the remineralization of its iron contents. On average throughout the experiment, and using the Fe:C ratio expected for a flagellate bloom $\left(40 \mu \mathrm{mol} \mathrm{Fe}(\mathrm{mol} \mathrm{C})^{-1}\right)$, we estimate that the daily iron uptake requirement to sustain gross primary production $\left(0.12 \mathrm{~mol} \mathrm{C} \mathrm{m}^{-2}\right.$ day $\left.^{-1}\right)$ was $\sim 5 \mu \mathrm{mol} \mathrm{Fe} \mathrm{m}^{-2}$ day $^{-1}$. Using the daily grazing rate of $C$. simillimus copepods of $\sim 43 \%$ of the

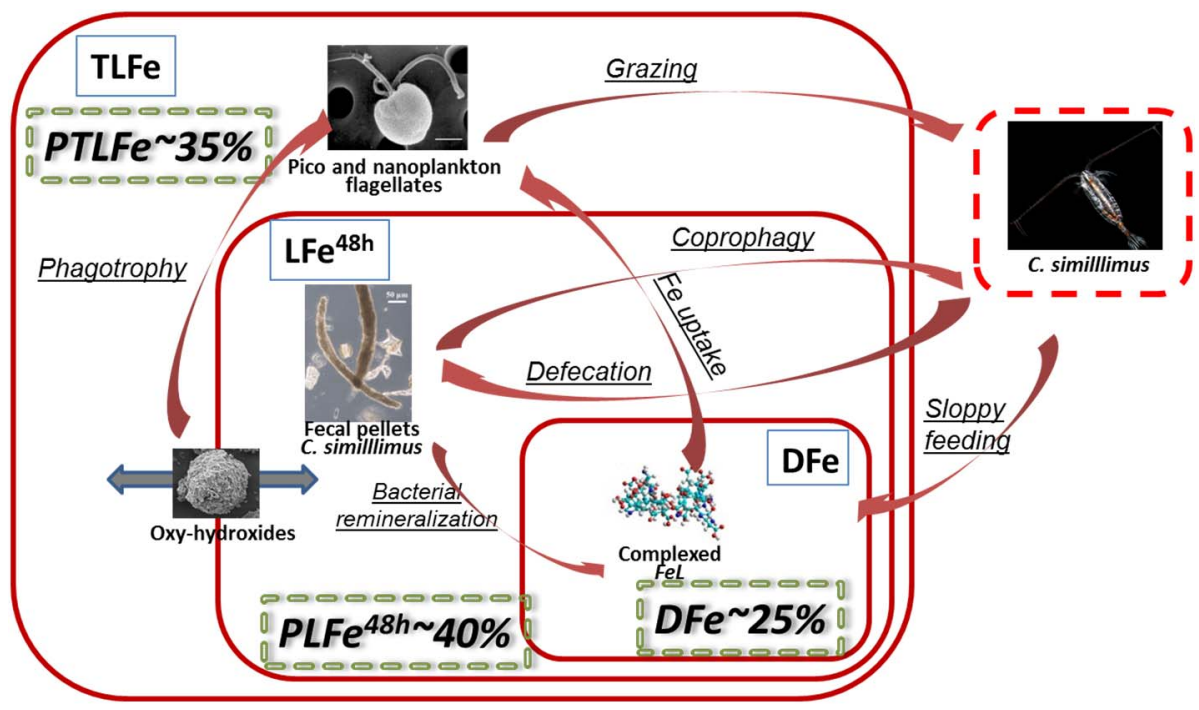

Fig. 8. Major iron stocks and fluxes in the ML during the LOHAFEX experiment. Boxes enclosed by continuous red lines correspond to those concentrations determined according to the analytical protocol used in this work. Boxes enclosed by broken red lines indicate pools of iron that could not be determined (swimming organisms are not sampled by standard sampling gear). Box sizes are not to scale. Pictures indicate the chemical species or type of organism dominating the iron pool in each specific box. Minor iron fluxes are not shown in the interests of clarity. Red arrows indicate fluxes of iron between fractions. The approximate contribution of every fraction to TLFe stocks during the dilution period are indicated in italics enclosed in green dashed lined boxes. (For interpretation of the references to color in this figure legend, the reader is referred to the web version of this article.) 
primary production (Martin et al., 2013) and a 50\% loss as sloppy feeding (Møller et al., 2003) we estimate daily fluxes of iron among the fractions defined in this work. Accordingly, $\sim 1 \mu \mathrm{mol} \mathrm{Fe}{ }^{-2}$ day $^{-1}$ should have been digested and excreted as fecal pellets and another $\sim 1 \mu \mathrm{mol} \mathrm{Fe} \mathrm{m}^{-2}$ day $^{-1}$ dispersed by sloppy feeding. Unfortunately it is impossible to estimate transfers caused by coprophagy and bacterial activity. The daily transfers estimated above would represent minor daily changes in the PTLFe standing stocks but they are large enough to substantially modify the DFe and PLFe ${ }^{48}$ h stocks over the course of a few days.

During the second fertilization, the addition of iron in great excess of its solubility presumably led to the rapid formation of iron-rich aggregates, an undetermined percentage of which could have escaped scavenging via phagotrophy by the flagellate community. This process would explain why significantly higher $\mathrm{PLFe}^{48 \mathrm{~h}}$ and iron per pellet concentrations were found in fertilized waters only after the second fertilization despite similar DFe and Chl-a concentrations and plankton community composition.

The above-mentioned processes can further explain the substantial accumulation of $\mathrm{PLFe}^{48 \mathrm{~h}}$ after the second fertilization in fertilized waters (Fig. 4). Immediately after fertilization phytoplankton other than flagellates could not take up significant amounts of Fe since the cells were iron replete (high in-patch $F_{V} / F_{M}$ ), however the formation of iron aggregates and DFe to PTLFe transfer rates via flagellate phagotrophy could have increased the PTLFe concentrations several fold when considering the $\mathrm{Fe}: \mathrm{C}$ ratios reported for incubations of flagellates feeding directly on iron colloids $\left(150 \mu \mathrm{mol} \mathrm{Fe}(\mathrm{mol} \mathrm{C})^{-1}\right)$ (Maranger et al., 1998). A significant part of the iron-enriched flagellates (a significant part of the PTLFe pool) could then be rapidly transferred to the more labile $\mathrm{PLFe}^{48 \mathrm{~h}}$ (via direct grazing or via intermediate predators such as dinoflagellates and ciliates, and defecation) and DFe pools (via sloppy feeding and pellet remineralization). This explains why the $\mathrm{PLFe}^{48 \mathrm{~h}}$ fraction suddenly tripled on day 24 only in fertilized waters, accounting for $\sim 40 \%$ of the TLFe standing stock.

\subsection{Implications for iron cycling and its study in the Southern Ocean}

The silica depleted condition encountered during LOHAFEX resulted in a flagellate dominated plankton community, producing short-lived and probably slow-sinking fecal pellets (Ploug et al., 2008) and low iron export fluxes (Martin et al., 2013). Using our novel analytical scheme we have shown that high iron inputs (colloidal and/or particulate) can be partially retained in the ML over long periods (at least several weeks) via storage in and release from copepod fecal pellets (Bowie et al., 2001). Copepod grazing and pellet recycling were facilitated by the dominance of flagellates in contrast to plankton communities dominated by diatoms. Efficient conversion from lithogenic to biologically available iron has been observed during the natural fertilization occurring around the Crozet Islands during microflagellate dominated blooms (Planquette et al., 2011). This process might be important for iron availability since silicic acid is usually depleted north of $60^{\circ} \mathrm{S}$ in the Southern Ocean (Sarmiento et al., 2004) and copepod biomass accounts for $>75 \%$ of the zooplankton biomass in the Southern Ocean (excluding Euphasia superba) (Atkinson et al., 2012).

Based on our results, we strongly suggest that more emphasis should be put on the investigation of particulate forms of iron in future work on iron fertilized (naturally or artificially) areas of the ocean. One methodological issue to consider is that sample volumes of $250-500 \mathrm{~mL}$ might not be sufficient to measure the contribution of $C$. simillimus fecal pellets (or other particles of different nature) at low concentrations. Pellet numbers were properly assessed in the ML (tens of pellets $\mathrm{L}^{-1}$ ) but under-sampling was a possibility for a few deep samples where concentrations of around 2 pellets $\mathrm{L}^{-1}$ were recorded. Our two-step leaching protocol could also be adapted to study Fe cycling with other plankton assemblages especially when grazing is dominated by other types of zooplankton characterized by different feeding strategies and producing fecal products with different characteristics (Cabanes et al., 2017).

The processes discussed above in combination with horizontal mixing and advection could also contribute to the large spatial extent and longevity of blooms in open waters of the Southern Ocean. The role of fecal material from other important species of the Southern Ocean in maintaining biological stocks via iron recycling, such as krill, whales and other marine mammals, has received increasing attention (Nicol et al., 2010; Ratnarajah et al., 2014; Schmidt and Atkinson, 2016; Smetacek and Nicol, 2005; Tovar-Sanchez et al., 2007). During LOHAFEX, the presence of krill and salps (and their fecal pellets) was negligible when compared to copepod numbers (M. Iversen, data not published). The combined activity of flagellates and copepods may play a key role in the efficient recycling of iron in the global ocean.

Finally, it has been pointed out that the prolonged, multi-stage life cycles of pelagic copepods, coupled with their global dominance in the biomass of plankton suggests that, from an evolutionary ecological viewpoint, they play a stabilizing role in ocean ecosystems by conditioning their environment: a form of "gardening" (Smetacek, 2008; Smetacek, 1985). The mechanisms by which copepods were involved in cycling $\mathrm{Fe}$ in the LOHAFEX study is entirely compatible with this "gardening" hypothesis.

\section{Acknowledgments}

We are grateful to Captain Stefan Schwarze and the crew of the RV Polarstern. All the members of the LOHAFEX community contributed to this work via discussion during the cruise and subsequent workshops.

This work was supported by the Government of Spain (MINECO CTM2008-01864-E/ANT and CTM2014-59244-C3-3-R). LML was supported by the Campus de Excelencia Internacional Program (Ministerio de Educación, Cultura y Deportes, España).

We would like to thank the associate editor and both anonymous reviewers for their significant contribution to the final version of this article.

\section{Appendix A. Supplementary data}

Supplementary data to this article can be found online at http://dx. doi.org/10.1016/j.marchem.2017.08.011.

\section{References}

Abraham, E.R., Law, C.S., Boyd, P.W., Lavender, S.J., Maldonado, M.T., Bowie, A.R., 2000. Importance of stirring in the development of an iron-fertilized phytoplankton bloom. Nature 407 (6805), 727-730.

Assmy, P., Smetacek, V., Montresor, M., Klaas, C., Henjes, J., Strass, V.H, Arrieta, J.M., Bathmann, U., Berg, G.M., Breitbarth, E., Cisewski, B., Friedrichs, L., Fuchs, N., Herndl, G.J., Jansen, S., Krägefsky, S., Latasa, M., Peeken, I., Röttgers, R., Scharek, R., Schüller, S.E., Steigenberger, S., Webb, A., Wolf-Gladrow, D., 2013. Thick-shelled, grazer-protected diatoms decouple ocean carbon and silicon cycles in the iron-limited Antarctic Circumpolar Current. Proc. Natl. Acad. Sci. U. S. A. 110 (51), 20633-20638. Atkinson, A., Ward, P., Hunt, B., Pakhomov, E., Hosie, G., 2012. An overview of Southern Ocean zooplankton data: abundance, biomass, feeding and functional relationships. CCAMLR. Science 19, 171-218.

de Baar, H.J.W., Boyd, P.W., Coale, K.H., Landry, M.R., Tsuda, A., Assmy, P., Bakker, D.C.E., Bozec, Y., Barber, R.T., Brzezinski, M.A., Buesseler, K.O., Boyé, M., Croot, P.L., Gervais, F., Gorbunov, M.Y., Harrison, P.J., Hiscock, W.T., Laan, P., Lancelot, C., Law, C.S., Levasseur, M., Marchetti, A., Millero, F.J., Nishioka, J., Nojiri, Y., van Oijen, T., Riebesell, U., Rijkenberg, M.J.A., Saito, H., Takeda, S., Timmermans, K.R., Veldhuis, M.J.W., Waite, A.M., Wong, C.S., 2005. Synthesis of iron fertilization experiments: from the iron age in the age of enlightenment. J. Geophys. Res. C 110 (9), $1-24$.

Barbeau, K., Moffett, J.W., Caron, D.A., Croot, P.L., Erdner, D.L., 1996. Role of protozoan grazing in relieving iron limitation of phytoplankton. Nature 380 (6569), 61-64.

van den Berg, C.M.G., 2006. Chemical speciation of iron in seawater by cathodic stripping voltammetry with dihydroxynaphthalene. Anal. Chem. 78 (1), 156-163.

Bowie, A.R., Maldonado, M.T., Frew, R.D., Croot, P.L., Achterberg, E.P., Mantoura, R.F.C. Worsfold, P.J., Law, C.S., Boyd, P.W., 2001. The fate of added iron during a mesoscale fertilisation experiment in the Southern Ocean. Deep-Sea Res. Part II 48 (11 - 12), 2703-2743.

Boyd, P.W., Jickells, T., Law, C.S., Blain, S., Boyle, E.A., Buesseler, K.O., Coale, K.H., 
Cullen, J.J., de Baar, H.J.W., Follows, M., Harvey, M., Lancelot, C., Levasseur, M., Owens, N.P.J., Pollard, R., Rivkin, R.B., Sarmiento, J., Schoemann, V., Smetacek, V., Takeda, S., Tsuda, A., Turner, S., Watson, A.J., 2007. Mesoscale iron enrichment experiments 1993-2005: synthesis and future directions. Science 315 (5812), 612-617.

Boye, M., Nishioka, J., Croot, P.L., Laan, P., Timmermans, K.R., de Baar, H.J.W., 2005. Major deviations of iron complexation during 22 days of a mesoscale iron enrichment in the open Southern Ocean. Mar. Chem. 96 (3-4), 257-271.

Cabanes, D.J.E., Norman, L., Santos-Echeandía, J., Iversen, M.H., Trimborn, S., Laglera, L.M., Hassler, C.S., 2017. First evaluation of the role of Salp fecal pellets on iron biogeochemistry. Front. Mar. Sci. 3 (289).

Chever, F., Bucciarelli, E., Sarthou, G., Speich, S., Arhan, M., Penven, P., Tagliabue, A., 2010. Physical speciation of iron in the Atlantic sector of the Southern Ocean along a transect from the subtropical domain to the Weddell Sea gyre. J. Geophys. Res. C 115 (10).

Croot, P.L., Bowie, A.R., Frew, R.D., Maldonado, M.T., Hall, J.A., Safi, K.A., La Roche, J., Boyd, P.W., Law, C.S., 2001. Retention of dissolved iron and Fe-II in an iron induced Southern Ocean phytoplankton bloom. Geophys. Res. Lett. 28 (18), 3425-3428.

Croot, P.L., Andersson, K., Ozturk, M., Turner, D.R., 2004. The distribution and specification of iron along 6 degrees $\mathrm{E}$ in the Southern Ocean. Deep-Sea Res. Part II 51 (22-24), 2857-2879.

De Jong, J., Schoemann, V., Lannuzel, D., Croot, P., De Baar, H., Tison, J.L., 2012. Natural iron fertilization of the Atlantic sector of the Southern Ocean by continental shelf sources of the Antarctic peninsula. J. Geophys. Res. G 117 (1).

Ebersbach, F., Assmy, P., Martin, P., Schulz, I., Wolzenburg, S., Nöthig, E.-M., 2014 Particle flux characterisation and sedimentation patterns of protistan plankton during the iron fertilisation experiment LOHAFEX in the Southern Ocean. Deep-Sea Res. I Oceanogr. Res. Pap. 89 (0), 94-103.

Feinberg, L.R., Dam, H.G., 1998. Effects of diet on dimensions, density and sinking rates of fecal pellets of the copepod Acartia tonsa. Mar. Ecol. 175, 87-96.

Fishwick, M.P., Sedwick, P.N., Lohan, M.C., Worsfold, P.J., Buck, K.N., Church, T.M., Ussher, S.J., 2014. The impact of changing surface ocean conditions on the dissolution of aerosol iron. Glob. Biogeochem. Cycles 2014GB004921.

González, H., Biddanda, B., 1990. Microbial transformation of metazoan (Idotea granulosa) faeces. Mar. Biol. 106 (2), 285-295.

Gonzalez, H.E., Smetacek, V., 1994. The possible role of the cyclopoid copepod Oithona in retarding vertical flux of zooplankton faecal material. Mar. Ecol. Prog. Ser. 113 (3), 233-246.

Gordon, R.M., Johnson, K.S., Coale, K.H., 1998. The behaviour of iron and other trace elements during the IronEx-I and PlumEx experiments in the Equatorial Pacific. DeepSea Res. Part II 45 (6), 995-1041.

Guillard, R.R.L., Ryther, J.H., 1962. Studies of marine planktonic diatoms. Can. J. Microbiol. 8, 229-239.

Hansen, B., Fotel, F.L., Jensen, N.J., Madsen, S.D., 1996. Bacteria associated with a marine planktonic copepod in culture. II. Degradation of fecal pellets produced on a diatom, a nanoflagellate or a dinoflagellate diet. J. Plankton Res. 18 (2), 275-288.

Harvey, M.J., Law, C.S., Smith, M.J., Hall, J.A., Abraham, E.R., Stevens, C.L., Hadfield, M.G., Ho, D.T., Ward, B., Archer, S.D., Cainey, J.M., Currie, K.I., Devries, D., Ellwood, M.J., Hill, P., Jones, G.B., Katz, D., Kuparinen, J., Macaskill, B., Main, W., Marriner, A., McGregor, J., McNeil, C., Minnett, P.J., Nodder, S.D., Peloquin, J., Pickmere, S., Pinkerton, M.H., Safi, K.A., Thompson, R., Walkington, M., Wright, S.W., Ziolkowski, L.A., 2011. The SOLAS air-sea gas exchange experiment (SAGE) 2004. Deep-Sea Res. Part II 58 (6), 753-763.

Hutchins, D., Bruland, K., 1994. Grazer-mediated regeneration and assimilation of Fe, Zn and Mn from planktonic prey. Mar. Ecol. Prog. Ser. 110, 259-269.

Iversen, M.H., Poulsen, L.K., 2007. Coprorhexy, coprophagy, and coprochaly in the copepods Calanus helgolandicus, Pseudocalanus elongatus, and Oithona similis. Mar. Ecol. Prog. Ser. 350, 79-89.

Jacobsen, T.R., Azam, F., 1984. Role of bacteria in copepod fecal pellet decomposition: colonization, growth rates and mineralization. Bull. Mar. Sci. 35 (3), 495-502.

Jansen, S., Henjes, J., Friedrichs, L., Krägefsky, S., Bathmann, U., 2007. Fate of Copepod Faecal Pellets During an Iron Induced Phytoplankton Bloom (EIFEX) in the Southern Ocean.

Johnson, K.S., Boyle, E., Bruland, K., Coale, K., Measures, C., Moffett, J., Aguilar-Islas, A., Barbeau, K., Bergquist, B., Bowie, A., Buck, K., Cai, Y., Chase, Z., Cullen, J., Doi, T., Elrod, V., Fitzwater, S., Gordon, M., King, A., Laan, P., Laglera-Baquer, L., Landing, W., Lohan, M., Mendez, J., Milne, A., Obata, H., Ossiander, L., Plant, J., Sarthou, G., Sedwick, P., Smith, G.J., Sohst, B., Tanner, S., Van den Berg, S., Wu, J., 2007. Developing standards for dissolved iron in seawater. Eos 88 (11), 131-132.

Kinugasa, M., Ishita, T., Sohrin, Y., Okamura, K., Takeda, S., Nishioka, J., Tsuda, A., 2005. Dynamics of trace metals during the subarctic Pacific iron experiment for ecosystem dynamics study (SEEDS2001). Prog. Oceanogr. 64 (2-4), 129-147.

Laglera, L.M., Santos-Echeandía, J., Caprara, S., Monticelli, D., 2013. Quantification of iron in seawater at the low picomolar range based on optimization of bromate/ammonia/dihydroxynaphtalene system by catalytic adsorptive cathodic stripping voltammetry. Anal. Chem. 85 (4), 2486-2492.

Lampitt, R.S., Noji, T., Von Bodungen, B., 1990. What happens to zooplankton faecal pellets? Implications for material flux. Mar. Biol. 104 (1), 15-23.

Landry, M.R., Constantinou, J., Latasa, M., Brown, S.L., Bidigare, R.R., Ondrusek, M.E. 2000. Biological response to iron fertilization in the eastern equatorial Pacific (IronEx II). III. Dynamics of phytoplankton growth and microzooplankton grazing. Mar. Ecol. 201, 57-72.

Lannuzel, D., Bowie, A.R., Remenyi, T., Lam, P., Townsend, A., Ibisanmi, E., Butler, E., Wagener, T., Schoemann, V., 2011. Distributions of dissolved and particulate iron in the sub-Antarctic and Polar Frontal Southern Ocean (Australian sector). Deep-Sea Res. Part II 58 (21 - 22), 2094-2112.
Liu, X.W., Millero, F.J., 2002. The solubility of iron in seawater. Mar. Chem. 77 (1), 43-54

Löscher, B.M., De Baar, H.J.W., De Jong, J.T.M., Veth, C., Dehairs, F., 1997. The distribution of Fe in the Antarctic circumpolar current. Deep-Sea Res. Part II 44 (1-2), 143-187.

Maldonado, M.T., Boyd, P.W., LaRoche, J., Strzepek, R., Waite, A., Bowie, A.R., Croot, P.L., Frew, R.D., Price, N.M., 2001. Iron uptake and physiological response of phytoplankton during a mesoscale Southern Ocean iron enrichment. Limnol. Oceanogr. 46 (7), 1802-1808.

Maranger, R., Bird, D.F., Price, N.M., 1998. Iron acquisition by photosynthetic marine phytoplankton from ingested bacteria. Nature 396, 248-251.

Martin, J.H., Fitzwater, S.E., Gordon, R.M., 1990. Iron deficiency limits phytoplankton growth in Antarctic waters. Global Biogeochem. Cycles 4, 5-12. http://dx.doi.org/ 10.1029/GB004i001p00005.

Martin, P., Van Der Loeff, M.R., Cassar, N., Vandromme, P., D'Ovidio, F., Stemmann, L., Rengarajan, R., Soares, M., González, H.E., Ebersbach, F., Lampitt, R.S., Sanders, R., Barnett, B.A., Smetacek, V., Naqvi, S.W.A., 2013. Iron fertilization enhanced net community production but not downward particle flux during the Southern Ocean iron fertilization experiment LOHAFEX. Glob. Biogeochem. Cycles 27 (3), 871-881.

Mazzocchi, M.G., González, H.E., Vandromme, P., Borrione, I., Ribera d'Alcalà, M., Gauns, M., Assmy, P., Fuchs, B., Klaas, C., Martin, P., Montresor, M., Nagappa, R., Naqvi, S.W.A., Smetacek, V., 2009. A non-diatom plankton bloom controlled by copepod grazing and amphipod predation: preliminary results from the LOHAFEX iron-fertilisation experiment. GLOBEC Int. Newsl. 15, 3-6.

Meskhidze, N., Nenes, A., Chameides, W.L., Luo, C., Mahowald, N., 2007. Atlanti Southern Ocean productivity: fertilization from above or below? Glob. Biogeochem. Cycles 21 (2).

Møller, E.F., Thor, P., Nielsen, T.G., 2003. Production of DOC by Calanus finmarchicus, C. glacialis and C. hyperboreus through sloppy feeding and leakage from fecal pellets. Mar. Ecol. Prog. Ser. 262, 185-191.

Nicol, S., Bowie, A., Jarman, S., Lannuzel, D., Meiners, K.M., van der Merwe, P., 2010. Southern Ocean iron fertilization by baleen whales and Antarctic krill. Fish Fish. 11 (2), 203-209.

Nishioka, J., Takeda, S., de Baar, H.J.W., Croot, P.L., Boye, M., Laan, P., Timmermans, K.R., 2005. Changes in the concentration of iron in different size fractions during an iron enrichment experiment in the open Southern Ocean. Mar. Chem. 95 (1-2), 51-63.

Nishioka, J., Takeda, S., Kondo, Y., Obata, H., Doi, T., Tsumune, D., Wong, C.S., Keith Johnson, W., Sutherland, N., Tsuda, A., 2009. Changes in iron concentrations and bio-availability during an open-ocean mesoscale iron enrichment in the western subarctic Pacific, SEEDS II. Deep-Sea Res. Part II 56 (26), 2796-2809.

Nodwell, L.M., Price, N.M., 2001. Direct use of inorganic colloidal iron by marine mixotrophic phytoplankton. Limnol. Oceanogr. 46 (4), 765-777.

Noji, T.T., Estep, K.W., Macintyre, F., Norrbin, F., 1991. Image analysis of faecal material grazed upon by three species of copepods: evidence for coprorhexy, coprophagy an coprochaly. J. Mar. Biol. Assoc. U. K. 71 (02), 465-480.

Nuester, J., Shema, S., Vermont, A., Fields, D.M., Twining, B.S., 2014. The regeneration of highly bioavailable iron by meso- and microzooplankton. Limnol. Oceanogr. 59 (4), 1399-1409.

Planquette, H., Sanders, R.R., Statham, P.J., Morris, P.J., Fones, G.R., 2011. Fluxes of particulate iron from the upper ocean around the Crozet Islands: a naturally iron fertilized environment in the Southern Ocean. Glob. Biogeochem. Cycles 25 (2).

Ploug, H., Iversen, M.H., Koski, M., Buitenhuis, E.T., 2008. Production, oxygen respiration rates, and sinking velocity of copepod fecal pellets: direct measurements of ballasting by opal and calcite. Limnol. Oceanogr. 53 (2), 469-476.

Powell, R.T., King, D.W., Landing, W.M., 1995. Iron distributions in surface waters of the South-Atlantic. Mar. Chem. 50 (1-4), 13-20.

Raiswell, R., 2011. Iceberg-hosted nanoparticulate Fe in the Southern Ocean: mineralogy, origin, dissolution kinetics and source of bioavailable Fe. Deep-Sea Res. Part II 58 (11-12), 1364-1375.

Raiswell, R., Canfield, D., Berner, R., 1994. A comparison of iron extraction methods for the determination of degree of pyritisation and the recognition of iron-limited pyrite formation. Chem. Geol. 111 (1), 101-110.

Ratnarajah, L., Bowie, A.R., Lannuzel, D., Meiners, K.M., Nicol, S., 2014. The biogeochemical role of baleen whales and krill in Southern Ocean nutrient cycling. PLoS One 9 (12), e114067.

Rue, E.L., Bruland, K.W., 1997. The role of organic complexation on ambient iron chemistry in the equatorial Pacific Ocean and the response of a mesoscale iron addition experiment. Limnol. Oceanogr. 42 (5 I), 901-910.

Saito, H., Ota, T., Suzuki, K., Nishioka, J., Tsuda, A., 2006. Role of heterotrophic dinoflagellate Gyrodinium sp in the fate of an iron induced diatom bloom. Geophys. Res. Lett. 33 (9).

Sarmiento, J.L., Gruber, N., Brzezinski, M.A., Dunne, J.P., 2004. High-latitude controls of thermocline nutrients and low latitude biological productivity. Nature 427 (6969), 56-60.

Sarthou, G., Vincent, D., Christaki, U., Obernosterer, I., Timmermans, K.R., Brussaard, C.P.D., 2008. The fate of biogenic iron during a phytoplankton bloom induced by natural fertilisation: impact of copepod grazing. Deep-Sea Res. Part II 55 (5-7), 734-751.

Sato, M., Takeda, S., Furuya, K., 2007. Iron regeneration and organic iron(III)-binding ligand production during in situ zooplankton grazing experiment. Mar. Chem. 106, $471-488$.

Schmidt, K., Atkinson, A., 2016. Feeding and food processing in Antarctic krill (Euphausia superba Dana). In: Biology and Ecology of Antarctic Krill. Springer, pp. 175-224.

Schmidt, M.A., Hutchins, D.A., 1999. Size-fractionated biological iron and carbon uptake along a coastal to offshore transect in the NE Pacific. Deep-Sea Res. Part II 46 
(11-12), 2487-2503.

Shi, Z., Bonneville, S., Krom, M.D., Carslaw, K.S., Jickells, T.D., Baker, A.R., Benning, L.G., 2011. Iron dissolution kinetics of mineral dust at low pH during simulated atmospheric processing. Atmos. Chem. Phys. 11 (3), 995-1007.

Smetacek, V.S., 1985. Role of sinking in diatom life-history cycles: ecological, evolutionary and geological significance. Mar. Biol. 84 (3), 239-251.

Smetacek, V., 2008. Are declining Antarctic krill stocks a result of global warming or the decimation of the whales? In: Duarte, C.M. (Ed.), The Impact of Global Warming on Polar Ecosystems. Fundacion BBVA, Spain, pp. 46-83.

Smetacek, V., Naqvi, S.W.A., 2008. The next generation of iron fertilization experiments in the Southern Ocean. Philos. Trans. R. Soc. A Math. Phys. Eng. Sci. 366 (1882), 3947-3967.

Smetacek, V., Naqvi, S.W.A., 2010. The Expedition of the Research Vessel "Polarstern" to the Antarctic in 2009 (ANT-XXV/3 - LOHAFEX). Berichte zur Polar- und Meeresforschung, Bremerhaven. http://hdl.handle.net/10013/epic.35169.

Smetacek, V., Nicol, S., 2005. Polar ocean ecosystems in a changing world. Nature 437 (7057), 362-368.

Smetacek, V., Assmy, P., Henjes, J., 2004. The role of grazing in structuring Southern Ocean pelagic ecosystems and biogeochemical cycles. Antarct. Sci. 16 (04), 541-558.

Smetacek, V., Klaas, C., Strass, V.H., Assmy, P., Montresor, M., Cisewski, B., Savoye, N., Webb, A., D'Ovidio, F., Arrieta, J.M., Bathmann, U., Bellerby, R., Berg, G.M., Croot, P., Gonzalez, S., Henjes, J., Herndl, G.J., Hoffmann, L.J., Leach, H., Losch, M., Mills, M.M., Neill, C., Peeken, I., Röttgers, R., Sachs, O., Sauter, E., Schmidt, M.M., Schwarz, J., Terbrüggen, A., Wolf-Gladrow, D., 2012. Deep carbon export from a Southern Ocean iron-fertilized diatom bloom. Nature 487 (7407), 313-319.

Sokolov, S., Rintoul, S.R., 2007. On the relationship between fronts of the Antarctic Circumpolar Current and surface chlorophyll concentrations in the Southern Ocean. J. Geophys. Res. 112 (C7).

Spokes, L.J., Jickells, T.D., 1996. Factors controlling the solubility of aerosol trace metals in the atmosphere and on mixing into seawater. Aquat. Geochem. 1, 355-374.

Thiele, S., Fuchs, B.M., Ramaiah, N., Amanna, R., 2012. Microbial community response during the iron fertilization experiment LOHAFEX. Appl. Environ. Microbiol. 78 (24), 8803-8812.

Thiele, S., Wolf, C., Schulz, I.K., Assmy, P., Metfies, K., Fuchs, B.M., 2014. Stable composition of the nano- and picoplankton community during the ocean iron fertilization experiment LOHAFEX. PLoS One 9 (11), e113244.

Tovar-Sánchez, A., 2012. Sampling approaches for trace elements determination in seawater. In: Pawliszyn, J. (Ed.), Comprehensive Sampling and Sample Preparation: Analytical Techniques for Scientists. Academic Press Elsevier, New York, pp. 317-334.

Tovar-Sanchez, A., Duarte, C.M., Hernández-León, S., Sañudo-Wilhelmy, S.A., 2007. Krill as a central node for iron cycling in the Southern Ocean. Geophys. Res. Lett. 34 (11).

Tsuda, A., Takeda, S., Saito, H., Nishioka, J., Kudo, I., Nojiri, Y., Suzuki, K., Uematsu, M., Wells, M.L., Tsumune, D., Yoshimura, T., Aono, T., Aramaki, T., Cochlan, W.P., Hayakawa, M., Imai, K., Isada, T., Iwamoto, Y., Johnson, W.K., Kameyama, S., Kato, S., Kiyosawa, H., Kondo, Y., Levasseur, M., Machida, R.J., Nagao, I., Nakagawa, F., Nakanish, T., Nakatsuka, S., Narita, A., Noiri, Y., Obata, H., Ogawa, H., Oguma, K., Ono, T., Sakuragi, T., Sasakawa, M., Sato, M., Shimamoto, A., Takata, H., Trick, C.G., Watanabe, Y.W., Wong, C.S., Yoshie, N., 2007. Evidence for the grazing hypothesis: grazing reduces phytoplankton responses of the HNLC ecosystem to iron enrichment in the western subarctic pacific (SEEDS II). J. Oceanogr. 63, 983-994.

Twining, B.S., Baines, S.B., 2013. The trace metal composition of marine phytoplankton. Annu. Rev. Mar. Sci. 5, 191-215.

Twining, B.S., Baines, S.B., Fisher, N.S., Landry, M.R., 2004. Cellular iron contents of plankton during the Southern Ocean iron experiment (SOFeX). Deep-Sea Res. I Oceanogr. Res. Pap. 51 (12), 1827-1850.

Wells, M.L., 2003. The level of iron enrichment required to initiate diatom blooms in HNLC waters. Mar. Chem. 82 (1-2), 101-114. 